\title{
Food consumption and diet quality choices of Roma in Romania: a counterfactual analysis
}

\author{
Pavel Ciaian $^{1} \cdot$ Andrej Cupák ${ }^{2,3} \cdot$ Ján Pokrivčák ${ }^{4,5} \cdot$ Marian Rizov $^{6}$
}

Received: 25 August 2016 / Accepted: 20 February 2018 / Published online: 25 March 2018

(C) The Author(s) 2018

\begin{abstract}
This paper analyses the diet quality aspect of food security of Roma in Romania. We employed a modified Blinder-Oaxaca decomposition technique using Household Budget Survey data for the period 2004-2011. The estimates suggest that Roma have inferior diet diversity compared to the non-Roma. Around one-third of the diet diversity gap is explained by the differences in observed socio-economic factors, whereas the remaining part of the gap is attributed to unobserved factors. We argue that the unexplained component of the diet diversity gap is caused by the discrimination of the Roma on the labour market and by their specific informal institutions.
\end{abstract}

Keywords Diet diversity $\cdot$ Diet diversity gap $\cdot$ Informal institutions $\cdot$ Discrimination $\cdot$ Roma

\section{Introduction}

According to FAO (2015) around 795 million people globally suffer from undernourishment meaning that one in nine people does not get sufficient food intake to be healthy and lead an active life. Food insecurity is especially a threat in the developing countries (Sub-Saharan Africa, Latin America, and Asia), where most food insecure people live. However, low income and marginalised groups in developed and transition economies also experience food insecurity. Such marginalised groups undoubtedly include the Roma population, one of the biggest ethnic minority groups in Europe (UNDP 2013; Council of Europe 2012; FRA 2014a, 2014b).

Pavel Ciaian

pavel.ciaian@ec.europa.eu

European Commission, Joint Research Centre, Seville, Spain

2 LIS Cross-National Data Center in Luxembourg, Esch-Belval, Luxembourg

3 National Bank of Slovakia, Bratislava, Slovakia

4 Faculty of Economics and Management, Slovak University of Agriculture, Nitra, Slovakia

5 Faculty of Economics, University of West Bohemia, Pilsen, Czech Republic

6 Lincoln Business School, University of Lincoln, Lincoln, UK
There are around 11 million Roma people living in Europe, mostly concentrated in the Central and Southeast European countries. Romania has one of the largest Roma populations in Europe. Around 16\% of European Roma live in Romania, whereas the share of Romanian Roma accounts for as much as $30 \%$ of all Roma in the European Union (EU). Some estimates put the proportion of Roma in the total Romanian population as high as $10 \%$ or more which is one of the highest proportions in Europe (Council of Europe 2012). Around 78\% of Roma in Romania live in households with incomes below the poverty line, ${ }^{1}$ while $22 \%$ of Romanians live below the poverty line (FRA 2014a). In most European countries including Romania, Roma populations face, to varying degrees, discrimination, which is reflected in racism and exclusion from the formal labour market as well as more difficult access to healthcare and education than the majority population (e.g., Tomovska 2010; European Commission 2012; FRA 2012, 2014a, 2014b; Bartoš et al. 2016; Ciaian and Kancs 2016a).

In this paper we aim to cast light on the food security situation of the Roma population in Romania. We focus on the diet quality aspect of food security of Roma and reveal possible cultural (institutional) and economic (marginalisation) forces determining their choices of diet. In the nutrition economics literature (e.g., Fernandez et al.

\footnotetext{
${ }^{1}$ Poverty line (or income below the national at risk-of-poverty level) is defined as household income below $60 \%$ of the national median equivalised disposable income. Equivalised disposable income is the sum of all net incomes within a household during a year adjusted per equivalent adult (FRA 2014a).
} 
1996; Hatloy et al. 1998; Arimond and Ruel 2004; Kant 2004; Matz et al. 2015) and food economics literature (e.g., Theil and Finke 1983; Jackson 1984; Thiele and Weiss 2003; Herzfeld et al. 2014; Braha et al. 2017) diet diversity is commonly employed as a proxy for diet quality. $^{2}$ It is established that consumption of a diverse diet has a positive impact on health and that diet diversity is a good indicator of food security at the household level. ${ }^{3}$ We proxied diet quality with three diversity indicators: the count of consumed food items, Simpson index, and Entropy index. To identify the Roma specificities in their diet choices, we compared them to that of the majority of the Romanian population. We also use other non-Roma minorities (Hungarian and other minorities) as control groups to test the importance of the diet quality differential with the non-Roma population. We studied the quality of food diet of the Romanian Roma population using the counterfactual decomposition technique introduced by Blinder (1973) and Oaxaca (1973), which is often used to estimate mean outcome differences among groups (e.g., Fairlie 1999; Schaafsma and Sweetman 2001; Frenette and Morissette 2005; Drydakis 2012; Sen 2014; Croucher et al. 2018). Household Budget Survey (HBS) were obtained from the Romanian National Institute of Statistics (NIS) covering the period 2004-2011.

Food insecurity and specifically diet quality of ethnic minorities have been studied mainly in the United States. For example, Coleman-Jensen et al. (2014) have shown that Hispanic (Latino) households are more than twice as likely to be food insecure as regular white (Caucasian) households $-24 \%$ versus $11 \%$. Food insecurity and resulting poor health of minority ethnic groups is usually due to significantly lower incomes, higher poverty and unemployment rates and worse access to food assistance programs (e.g., Alaimo et al. 1998; Himmelgreen et al. 2000; Arimond and Ruel 2004).

Papers analysing diets of the Roma ethnic group in Europe are rather limited. Existing studies focus on Roma food security in terms of access to food, importance of food expenditure in total income or severity of hunger and malnutrition without going into details of food composition and diet quality (e.g., Masseria et al. 2010; Voko et al. 2009; FRA 2014a). The most comprehensive surveys of the Roma's socio-economic

\footnotetext{
$\overline{2}$ Diet diversity is considered an important determinant of the diet quality of individuals. However, there are other factors which impact diet quality which includes most importantly macro and micro nutrients contained in the consumed foods and the quantity and quality of the calorie intake (Braha et al. 2017). For example, Kennedy (2004) showed that variety in certain energyrich food items may lead to overweight and obesity and ultimately poor health.

${ }^{3}$ The food security concept formulated in the Declaration on World Food Security, adopted in 1996, encompasses supply and demand factors and includes the following four key elements: availability, access, utilization, and stability. In general, the access to food is perceived to be incorporated in the proportion of income spent on food, whereas the utilization of food is captured by the diversity (quality) of diet for which access is a necessary condition (Carletto et al. 2013; FAO 2015; Braha et al. 2017).
}

situation in Europe were conducted by the European Commission, the UNDP, and the World Bank in 17 European countries (UNDP 2014; FRA 2012, 2014a, 2014b). The parts of the surveys focusing on Roma food security evaluated Roma food security in general and found that Roma perform significantly worse than the similar non-Roma populations. On average in the EU, around $40 \%$ of Roma live in households which experienced hunger at least once per month. Further, childhood hunger rates were at least three times higher for the Roma than for the similar non-Roma populations. Romania is one of the worst performing countries in these food security indicators (FRA 2014a). There are also some studies on differences in health status between Roma and other ethnic groups, e.g. in Bulgaria, Romania, and Hungary. These studies conclude that the likelihood of selfreporting bad health status is significantly higher for Roma than for non-Roma populations (e.g., Masseria et al. 2010; Voko et al. 2009). An exception is the UNDP (2013) study which collected a more detailed survey data on diets of Roma households in Slovakia. The results of this survey indicate that the Roma in Slovakia spend 40-50\% of their total income on food, which is significantly higher compared to the national average (around 15-20\%). Further, the results suggest that healthier food items were found only in minimal amounts while cheaper and lower quality alternatives predominated in Roma's diets (UNDP 2013). However, this survey was relatively small and it did not include non-Roma populations, which does not allow comparison of Roma's diet quality with the majority population or testing of the statistical significance in the observed differences in diet behaviour.

Our main contribution to the literature is the use of unique HBS survey data that contain detailed information on the diet and ethnicity of surveyed households. These allow us to evaluate Roma dietary behaviour and compare it with the majority population as well as with other minorities living in Romania. To our knowledge, there are no comparable studies on diet quality for the Roma ethnic group in Europe. Given the strong correlation between diet quality and food security (e.g., Hoddinott and Yohannes 2002; Ruel 2002; Champagne et al. 2007; Faber et al. 2009) this is a significant omission in the literature. Our second contribution to the literature is the application of the Blinder-Oaxaca decomposition technique to the analyses of the nutritional security and vulnerability across ethnic groups.

The paper is organised as follows. The next section provides a brief overview of the recent history of Roma ethnic group in Romania, which is followed by the third section explaining the determinants of food consumption patterns of Roma and how these differ from non-Roma's. The fourth section presents the methodology for the measurement and decomposition of the diet diversity. Data used in the estimation are presented in the fifth section and the sixth section describes the results, while the last section concludes. 


\section{Recent history of Roma in Romania}

The current situation of the Roma in Romania is heavily affected by the Communist regime installed in Eastern Europe after World War II and the subsequent transition process following the collapse of Communism in 1989. The general policy objective of the Communist regime in Romania was to gradually assimilate the Roma ethnic group by restricting their culture, language and their traditional way of life. One consequence of this policy was that Roma underwent significant occupational transformation; many of them were forced to abandon their traditional occupations and switch to unskilled or semi-skilled jobs. The main type of employment of Roma during the Communist period included seasonal labour in cooperative or state farms and unskilled jobs in the industrial sector. Yet an additional important activity of some Roma during the Communist period was trade. The shortage of basic goods and services was a typical state of the economy under the Communist regime which provided for many Roma an opportunity to expand both their legal and semi-illegal trade activities. Although Communism contributed to the modernisation of Roma lifestyles, improvement of social and material condition and helped to create a Roma middle class (e.g., industrial workers, intellectuals), in general Roma underwent a process of socio-economic marginalisation by becoming a category of population with the most acute social and economic problems to a degree that was not observed in Romania in the past (Troc 2002; Achim 2004).

After the fall of Communism in 1989, the restrictions on cultural freedom and the use of Roma language were abolished. However, the economic situation of Roma deteriorated drastically during the transition from central planning to market economy (especially in the early years). Due to widespread discrimination, low education and skills, Roma were the first to lose their jobs. The transition to market economy also had an adverse impact on the Roma who were involved in trading activities during the former Communist system. Given that commercial trade became legal and a recognised activity, Roma lost to a large extent their market position. As a result, most Roma remained long-term unemployed and mostly relied on seasonal and occasion types of jobs (Barany 2004; Crețan and Turnock 2009). Poverty and social exclusion forced many Roma to search for alternative activities such as begging, petty theft, black market trade and other types of semi-illegal activities, thus further aggravating conflict and discrimination tendencies in the majority non-Roma population (Troc 2002; Marushiakova and Popov 2003; Năstasă and Salat 2003; Crețan and Turnock 2009; Ciaian and Kancs 2016a). The adverse impacts of the previous Communist regime and the subsequent developments during the transition process had repercussions on Roma exclusion from the majority population socio-economic system and on the ability of Roma communities to ensure sufficient and stable incomes needed for healthy food consumption patterns.

\section{Hypothesis development: Roma's food consumption patterns}

The aim of this paper is to provide an explanation for potential factors that may lead to different food consumption patterns of Roma compared to non-Roma populations. We focus on two key issues that strongly differ between Roma and non-Roma and may impact their diet choices. First, we consider the implications of Roma specific informal institutions on their food consumption patterns. Roma are governed by these (called Romaniya) ${ }^{4}$ which substitute for formal state institutions and sustain social order within their community (Fraser 1995; Weyrauch 2001; Leeson 2013). Second, we investigate the role of economic marginalisation of Roma in affecting their food consumption. Economic marginalisation of Roma is widespread, causing marked disparity in access to the labour market, income level and its volatility compared to the majority population. One of the main causes of the marginalisation of Roma is the discrimination coming from the majority Romanian population (Crețan and Turnock 2009; Tomovska 2010; European Commission 2012; FRA 2012; Ciaian and Kancs 2016a). Both factors may strongly impact the Roma's food consumption level as well as their diet quality (diet diversity).

\subsection{Roma informal institutions}

All aspects of Roma life, including consumption of food, are heavily affected by Romaniya. Romaniya rules are customary and oral, and are enforced and administered by a Roma informal enforcement system. They coexist with the host (formal national) legal order wherever Roma are present. Romaniya relies on a ritual belief system with its core concept of distinguishing between behaviour that is polluted (marimé) and pure (vujo). ${ }^{5}$ Marimé is perceived in Roma's belief system as morally, not necessarily physically, "dirty", but also spiritually (ritually) "dirty" and determines which actions and behaviours are accepted and are in line with rules (Fraser 1995; Weyrauch 2001; Leeson 2013; Ciaian and Kancs 2016a).

According to Romaniya, the main cause of pollution (marimé) is the human body. The human body is understood to be formed of pure and impure (polluted) parts with the waist representing the dividing borderline. The lower body is considered to be polluted, while the upper part is perceived as pure and clean. Any careless contact between the lower and upper bodies represents a marimé action and may lead, among others, objects, persons, food stuffs and discussion topics becoming polluted (marimé). Women are perceived as more

\footnotetext{
${ }^{4}$ Note that the apparent similarity between Romaniya and Romania is just a coincidence; both have a different meaning.

${ }^{5}$ The adherence to Romaniya of the Roma varies from community to community, however, many Romaniya rules are similar and vary only in the degree in which they are observed or applied (Patrin 2015).
} 
unclean and are thus represent a higher source of contamination. On the other hand, older Roma are less subject to marimé, while children are clean until puberty (except for the first 6 weeks after the birth). Non-Roma (Gaje) are by default polluted because they do not follow the Romaniya rules and thus they represent a permanent danger of contamination. This also holds for non-Roma places (e.g., hospitals, buses, schools, offices, homes) and non-Roma objects (e.g., their prepared food), which by definition are polluted (Fraser 1995; Weyrauch 2001; Leeson 2013; Ciaian and Kancs 2016a, b). ${ }^{6}$

The Roma belief system based on marimé implies a whole series of social boundaries to Roma, requiring, among others, food preparation and consumption to respect certain taboos. Given that women are more unclean in certain situations it also has implications for food preparation and consumption. A woman in menstrual cycle is marimé and must avoid contact with others. She has to eat alone and cannot prepare food for others. The same holds for pregnant women. They are expected to eat alone and from their own dishes. Dishes and cutlery cannot be shared with non-Roma guests. There are many other taboos with implications for food consumption: food in which hair has been found must be destroyed; eating with unwashed hands is a marimé act; blowing the nose or sneezing makes food polluted; a man that has touched a women's skirt cannot handle food before washing his hands; food that falls on the floor is polluted and must be destroyed; and women may pollute food if they do not shield it properly from their lower halves. Further, marimé rules restrict consumption of certain foods (e.g., horse meat), while certain foods can only be eaten at certain events (e.g., peanuts only at a funeral feast) (Fraser 1995; Weyrauch 2001; Leeson 2013; Ciaian and Kancs 2016a).

An important source of impurity and pollution are nonRoma places and objects (including food) because they do not adhere to the Romaniya belief system. Food procured from non-Roma is perceived to be polluted and thus should be avoided. ${ }^{7}$ To circumvent or reduce the chance of marimé, Roma may avoid consuming food obtained outside the Roma community (e.g., in restaurants or hospitals). When eating away from home, a strategy often applied by Roma to reduce or eliminate risk of pollution is the use of disposable dishes and cutlery, eating pre-packed food and drinking from bottles or cartons (Weyrauch 2001; Honer and Hoppie 2004; Leeson 2013; Ciaian and Kancs 2016a,b).

\footnotetext{
${ }^{6}$ The enforcement of Romaniya rules is carried out at different levels of Roma society depending on the gravity of the case. The day-to-day conflicts within the community are handled by the clan (vitsa) chief. Inter-clan conflicts are mediated by chiefs of clans (divano). The highest (third) level of conflict resolution is the informal court system kris applied when the case cannot be settled at lower level or if the cases are serious (Weyrauch 2001; Leeson 2013; Ciaian and Kancs 2016a, b).

${ }^{7}$ Children are an exception because they are less subject to marimé rule.
}

Another factor that may have affected the eating habits of Roma - not necessarily linked to Romaniya - is their nomadic way of life practiced particularly in the past. Their diet was restricted to a large extent to what was readily available. For example, this included wild fruits, berries, leafy plants, and small mammals. As Roma have gradually come into greater contact with non-Roma people and a sedentary lifestyle, their eating habits have conformed closer to those of the non-Roma (Patrin 2015). However, some habits have been preserved until the present and still affect dietary choices, food preparation and consumption.

Food consumption habits of Roma have several implications for diet diversity. First, the key effect is the restriction of consuming only food prepared by Roma. Roma rules imply prohibition of consumption of food prepared by non-Roma. Thus, preference is given to Roma self-prepared food. This increases the cost of some foods or imposes specific requirements on their preparation and handling if acquired away from home (e.g., wrapped take-away foods) which reduces the set of consumption options available to Roma. Second, certain foods are restricted and not allowed by Roma rules. Third, low availability and diversity of food due to the nomadic way of life in the past may still affect the present dietary choices. All these elements are specific to Roma and are expected to lead to different dietary behaviour of Roma as compared to the non-Roma population.

We therefore hypothesise:

Hypothesis 1: The Roma informal institutions are an important factor in the choices of Roma diets and cause lower diversity of Roma's diets compared to those of non-Roma.

\subsection{Roma economic marginalisation}

The marginalisation and segregation experienced by Roma in Europe, including in Romania, adversely impacts their contemporaneous and expected income streams which reduces Roma's access to sufficient food, particularly of better quality, and ultimately distorts Roma's diet diversity choices (Theil and Finke 1983; Jackson 1984; Dercon 2002). The economic marginalisation of Roma is largely due to labour market discrimination, which hinders equal access to employment opportunities compared to non-Roma. Adverse impact of this discrimination is reflected in lower labour market participation, employment in inferior jobs, lower income, job instability and income volatility (European Commission 2012; FRA 2014a; Bartoš et al. 2016; Ciaian and Kancs 2016a,b).

Labour market discrimination leads to high unemployment among Roma people in Romania. O'Higgins and Ivanov (2006) conducted a survey in Romania in 2004 and found that Roma's unemployment rate was $45 \%$ compared with $29 \%$ of 
the control group of non-Roma populations living in close proximity to Roma. Further, the survey revealed that most Roma suffered from long-term unemployment. Among all unemployed Roma, 88\% had not had a job since 1996 or earlier. Because of long-term unemployment, Roma were not eligible for unemployment benefits and could obtain only minimal social assistance from the government.

High and long-term nature of unemployment negatively impact job and income stability of Roma households in Romania. Roma workers usually have access only to temporary or occasional types of jobs such as seasonal works on farms, specialised crafts (e.g., music), trade on local markets, as well as semi-illegal activities (e.g., begging). According to FRA (2012), only around 29\% of Roma were reported to be in paid employment in Romania compared to $38 \%$ for similar non-Roma population and significantly below the national average of 49\% (Troc 2002; O'Higgins and Ivanov 2006). According to FRA (2014a), a considerable share (66\%) of Roma in paid employment face precarious employment conditions: $60 \%$ hold ad-hoc jobs, $4 \%$ are self-employed and $1 \%$ are employed part-time, while only $34 \%$ have a full time job.

The Roma labour market participation gaps are reflected in low and volatile income. According to FRA (2014a), the large majority of Roma households (78\%) have an income below the national at risk-of-poverty level (i.e., lower than $60 \%$ of the national median equivalised disposable income) in Romania, compared to $35 \%$ of similar non-Roma households and compared to the national average of $22 \%$. According to the World Bank (2005) social mapping survey, the minimum income guarantee and occasional activities are the main income sources of Roma communities in Romania. The minimum income guarantee is a specific income source for Roma communities from the periphery of villages, while occasional activities are a more common source of income for Roma communities in larger towns.

Dercon (2002) and Dercon and Krishnan (2000) argue that the vulnerability of households with risky (and volatile) income stream is high and is reflected in fluctuations in consumption, which adversely impacts nutrition and health of household members. Although households operating in risky environments may develop risk-coping strategies (e.g., income diversification, self-insurance through savings, informal insurance and credit markets, informal risk-sharing) that mitigate the consumption losses (including food) in periods when income is low, these strategies do not fully eliminate the variability in consumption (Dercon 2002). Jalan and Ravallion (1999) report that $40 \%$ of an income shock is passed onto current consumption for the poorest wealth decile, whereas consumption by the richest third of households is protected from almost $90 \%$ of income shocks. Further, coping with recurrent income declines is more difficult than coping with a single income shock. Using panel data from Pakistan, Alderman (1996) found that households exhibit greater difficulty in smoothing consumption for successive income shocks than for a single shock. As reported above, most Roma households in Romania face recurrent income shocks; because of labour market discrimination they usually rely on occasional or part-time jobs which, based on the above reasoning, could adversely affect their diet (quality) choices.

As Troc (2002, p. 22) puts it, based on an extensive study of Roma's employment from the village of Nusfalau located in North-West Romania (Transylvania): "The only regular source of money is the children's allowance. A family with eight children below the age of eighteen, for example, receives 730,000 lei/month (33 USD). The day when the allowance comes is the day of debt payments, especially payments for the food products bought from the single shop that accepts the in-debt system for Roms ("Ali Laly"). According to their sayings it is also the only day when the family eats meat."

Further, Troc (2002, p. 22) writes: "During summer the Roms could make some money by gathering wild fruits from the near-by forests. When the time of the mushrooms come they organize en masse gathering campaigns ("we stay in the forest and wait for them to grow", told me a Rom). For a week or so they eat only mushrooms, then they sell some to Romanians from the village of Bozies. At best they get 20,000 (1 USD) for one pail". There could also be intra family impacts on food consumption, especially those in poverty. According to Troc (2002, p. 26): "When the food is scarce, the first who are fed are children. With few exceptions, women seem to be the most disadvantaged members of the households."

We therefore hypothesise:

Hypothesis 2: Inferior employment opportunities and volatility of labour income cause lower diversity of Roma's diets compared to those of non-Roma's one.

\section{Methodology: measuring diet diversity and an econometric approach}

\subsection{Measuring diet diversity}

Literature on nutrition (e.g., Hatloy et al. 1998; Kant 2004; Matz et al. 2015) shows that consumption of diverse diet has positive impact on health and thus diet diversity is a good indicator of diet quality and household food and nutritional security. Hoddinott (1999) offers a comprehensive overview of frameworks for measuring household diet diversity and food security. In this paper we employed three measures of the diet diversity of Roma households: (i) the count of food items consumed (CM), (ii) diversity measured by Simpson index (SI), and (iii) diversity measured by Entropy index (EI). 
The number of food items consumed over a defined period, known as Count Measure (CM), is a simple and commonly used indicator of diet diversity (e.g., Jackson 1984; Kant 1996). CM is calculated as a sum of dummy variables $Q_{i}$ taking value of 1 if a household consumes $i$-th food item in its basket and 0 otherwise: $C M=\sum_{j=0}^{N} Q_{i}$. The indicator is theoretically founded assuming an ordinal utility function. Similarly, SI and EI, which are also theoretically derived, are commonly used indicators for measuring diet diversity in the literature on consumer behaviour in respect of food (e.g., Theil and Finke 1983; Thiele and Weiss 2003; Herzfeld et al. 2014). The Simpson Index, also known as Berry Index, is calculated as $S I=1-\sum w_{i}^{2}$, where $w_{i}$ is the budget share of the $i$-th (disaggregated) food item in the total food expenditure (basket). The Entropy Index is calculated as $E I=\sum w_{i} \log \left(1 / w_{i}\right)$. Note that EI places a larger weight on food items with smaller budget proportions and thus it is sensitive to differences in the number of small items in the consumption basket. Unlike CM, the advantage of both SI and EI is that they take into consideration the relative importance of each food item consumed in the food basket. Hence, it follows that the magnitude of SI and EI (i.e. diet diversity) is higher when more food items are consumed in equal proportions than in the case of fewer food items consumed in different proportions (Braha et al. 2017).

\subsection{Decomposition analysis}

The main objective of this paper is to analyse the differences in the diet diversity of Roma and non-Roma ethnic groups. To do this we apply a modified Blinder-Oaxaca (Blinder 1973; Oaxaca 1973) framework. The Blinder-Oaxaca decomposition technique has been predominantly used in labour economics literature to study gaps in wages and employment, mostly across ethnic groups and gender (e.g., Drydakis 2012; Croucher et al. 2018). Recently, this method has also been applied in the field of public health literature to explore differences in obesity across racial groups, gender, and regions in North America (e.g., Sen 2014). A similar decomposition method has also been applied to study rural-urban differences in children's dietary diversity in Ethiopia (Hirvonen 2016). We apply the Blinder-Oaxaca decomposition technique to decompose differentials in diet quality choices between Roma and non-Roma. That is, we use this method to distinguish between the importance of objective (observable) household and individual characteristics and (unobservable) cultural and ethnic traditions as well as discrimination and marginalisation effects on Roma compared to the non-Roma population in Romania.

It is important to point out that we apply the BlinderOaxaca decomposition to a theoretically well-defined diet diversity demand function which allows us to clearly identify observable factors affecting the diet diversity choice. In our case, the decomposition divides the mean diet diversity differential between Roma and non-Roma groups into two parts one "explained" by group differences in observable characteristics such as income, prices, and other observed characteristics (e.g., education, age, employment status), and another that cannot be accounted for by (observed) differences in diet diversity determinants. This "unexplained" part can be interpreted as a measure of Roma-specific institutions as well as impacts of discrimination against Roma and the induced economic marginalisation effects; it also subsumes the effects of group differences in unobserved (unaccounted) predictors which are minimised considering our theoretically founded specification. Let us consider two ethnic groups, $A$ (nonRoma) and $B$ (Roma). To identify the contribution of group differences to the overall outcome difference, we can write:

$$
\begin{aligned}
R= & \left\{E\left(X_{A}\right)-E\left(X_{B}\right)\right\} \beta_{B}+E\left(X_{B}\right)\left(\beta_{A}-\beta_{B}\right) \\
& +\left\{E\left(X_{A}\right)-E\left(X_{B}\right)\right\}\left(\beta_{A}-\beta_{B}\right)
\end{aligned}
$$

Thus, we have a "threefold" decomposition where the outcome differential $R$ is divided into three components, $R=E+$ $C+I$. The first component, $E=\left\{E\left(X_{A}\right)-E\left(X_{B}\right)\right\} \beta_{B}$ amounts to the part of the differential in diet diversity that is due to group differences in the observed predictors (known as the "endowment effect"). The second component, $C=E\left(X_{B}\right)\left(\beta_{A}-\beta_{B}\right)$, accounts for the contribution to the differential in diet diversity caused by differences in the coefficients (including difference in the intercept). These can be explained as differences in valuations of the two groups compared. The third component, $I=\left\{E\left(X_{A}\right)-E\left(X_{B}\right)\right\}\left(\beta_{A}-\beta_{B}\right)$, is an interaction term which takes into consideration the fact that differences in endowments and coefficients are present simultaneously. The decomposition is defined from the group B's standpoint: the predictors' group differences are weighted by the coefficients of group $B$ to determine the endowment effect $(E)$. The endowment effect $E$ captures the expected change in group $B$ 's mean diet diversity if the group $B$ 's predictor levels are set to the group $A$ 's predictor levels. Similar interpretation holds for the "coefficient effect" $(C)$ component, where the differences in coefficients are weighted by group $B$ 's predictor levels. That is, the $C$ component captures the expected change in group $B$ 's mean diet diversity if group $B$ received group $A$ 's coefficients (Croucher et al. 2018). ${ }^{8}$

An important alternative decomposition approach applied in the literature is based on an approach which applies a nondiscriminatory coefficient vector to determine the contribution of the differences in the observed predictors to the outcome (diet diversity) differential (Croucher et al. 2018). Let $\beta^{*}$ be

\footnotetext{
${ }^{8}$ Croucher et al. (2018) offer an example of a decomposition application in a context different from ours - the employability perceptions by London's low paid workers - which is nevertheless relevant to our analysis.
} 
such a non-discriminatory coefficient vector that would exist if there were no differences between group $A$ and group $B$. The outcome difference is then

$$
R=\left\{E\left(X_{A}\right)-E\left(X_{B}\right)\right\} \beta^{*}+\left\{E\left(X_{A}\right)\left(\beta_{A}-\beta^{*}\right)+E\left(X_{B}\right)\left(\beta^{*}-\beta_{B}\right)\right\}(2)
$$

This leads to the decomposition of diet diversity differentials into two components, $R=Q+U$. The first component, $Q=\left\{E\left(X_{A}\right)-E\left(X_{B}\right)\right\} \beta^{*}$, is the part of the diet diversity differential explained by group differences in the predictors (i.e. the "quantity effect" which resembles the endowment effect above), while the second component, $U=E\left(X_{A}\right)\left(\beta_{A}-\beta^{*}\right)+$ $E\left(X_{B}\right)\left(\beta^{*}-\beta_{B}\right)$, is the unexplained part. In our context, the latter could be attributed to unobservable factors such as discrimination and marginalisation, Roma-specific institutions and cultural factors.

The unexplained part in (2) is sometimes further decomposed; $U$ can be expressed as $U=E\left(X_{A}\right) \delta_{A}-E\left(X_{B}\right) \delta_{B}$ : the unexplained component of the differential is subdivided into a part, $U_{A}=E\left(X_{A}\right) \delta_{A}$ that measures discrimination, institutions and cultural traits in favour of group $A$ 's diet diversity and a part, $U_{B}=-E\left(X_{B}\right) \delta_{B}$ that quantifies discrimination, institutions and cultural traits effects against group $B$ 's diet diversity. Thus, $U_{A}$ and $U_{B}$ have opposite interpretations. A positive value of $U_{A}$ reflects positive contribution towards group $A$ 's diet; a positive value of $U_{B}$ indicates negative contribution towards group $B$ 's diet.

The application of this approach is more demanding because it requires estimation of the unknown nondiscriminatory coefficients vector $\beta^{*}$. Following the theoretical framework developed by Neumark (1988), the coefficients vector $\beta^{*}$ can be estimated from a pooled regression over both considered groups. Oaxaca and Ransom (1994) and others propose weighting models taking into account the relative size of the analysed groups. A limitation identified in the approaches proposed by Neumark (1988) and Oaxaca and Ransom (1994) is that some of the unexplained part of the diet diversity differential might be improperly transferred into the explained part. To avoid this problem in our analyses, we considered a group indicator in the pooled model as an additional covariate (Croucher et al. 2018).

\section{Data and variables}

We studied food demand patterns and diversity of diet of the Roma ethnic group relative to other non-Roma ethnic groups using the Household Budget Survey (HBS) of Romania covering the period from 2004 to 2011. The key advantage of this database is that it contains detailed information of food composition of the surveyed households alongside their ethnicity.
The Romanian HBS is organised as a quarterly survey on a sample of around 9000 dwellings. It contains information on household's income, sources of income (cash entries from salaries, pensions, social services, sale of farm products, and from other activities), household's expenditure as well as quantities of food and beverages consumed. HBS also contains information on household's location, household's characteristics, residence area characteristics, period of data collection, and information on household's ethnic group. Following the ethnic population structure, the majority of surveyed households are Romanians. Other ethnic groups include Hungarians, Germans, Serbs and Bulgarians, as well as Roma.

Following previous studies on diet diversity (Jackson 1984; Lee and Brown 1989; Thiele and Weiss 2003; Herzfeld et al. 2014) we specify a demand for a diet diversity equation which is based on a standard (ordinary) demand formulation. To account for income level and food prices faced by households, we considered total household monthly income (income), and the amount paid per unit of food item (food_price). We also included income squared variable (income_2) to account for potential non-linear relation between income level and diet diversity. In an attempt to control for the type of income source and potentially for the income uncertainty and the importance of employment patterns (Hypothesis 2), we considered a set of variables including the share of allowances (share_allowances) and share of salaries (share_salaries) in total household monthly income and a dummy variable capturing if the household head was working during the reference month (d_working). The share of food expenditure in the total household disposable income $(w$ food) accounts for the distribution of household consumption between food and non-food items. Given that households' composition and characteristics may importantly impact the household dietary choices, we included variables measuring household size ( $h$ _size), a dummy variable indicating whether a household has at least one dependent child (d_children), gender of household's head (d_male), age and age squared of household's head (age, age_2), and a set of dummy variables indicating level of education of household head (edu_primary, edu_secondary, edu_tertiary). Further, an important driver of diet composition and diversity could be the location of the household, in rural or urban areas. This variable may capture own-food production as households in rural areas are expected to be more likely to own a plot of land and thus produce own food. For this reason we considered a dummy variable taking a value one if a household resides in an urban area and zero otherwise (urban). We also attempted to proxy regional differences by including a dummy variable for Bucharest-Ilfov capital region (d bucharest) taking a value one if the household is from this region and zero otherwise. Given that the HBS is a quarterly survey, we considered dummies to account for the quarter within the year for which the survey data were 
collected $(q 1, q 3)$, thus accounting for seasonality in consumption. Finally, to account for common change of food consumption pattern over time we also included a trend variable in the estimated equation (trend). Definitions of the variables used in estimations are summarised in Table 1.

\subsection{Ethnic groups}

We distinguish four ethnic groups in the paper: the majority Romanian households (d_romanian), Roma households (d_gypsy), Hungarian households (d_hungarian), and households belonging to other minorities (d_other). Alongside Roma, the Hungarian ethnic group is amongst the largest minorities in Romania. Table 2 shows the distribution of ethnic groups in the HBS survey for the covered period 2004-2011. In total, the survey includes 127,894 observations, out of which 115,978 (90.68\% of total sample) are Romanians, $8126(6.35 \%)$ are Hungarians, $2654(2.07 \%)$ are Roma, and $1137(0.89 \%)$ are other minorities. The share of Roma in the total sample corresponds relatively closely to the 2011 Census according to which Roma account for $2.8 \%$ of the total population in Romania. These official figures are significantly lower than those reported by the Council of Europe (2012) which suggests that the upper estimates of Roma in the total population may be as high as $12 \%$.

As reference group $A$ in the decomposition analysis we used three alternatives: the Romanian majority population, the Hungarian ethnic group, and "Other" minority group. We estimated dietary diversity differentials of Roma (group $B$ ) relative to each of these three non-Roma groups. The main purpose of including other non-Roma minorities (i.e., Hungarians and Other minorities) in our analysis was to use them as further control groups. This allowed us to test whether the estimated differences in Roma's diet diversity with respect to the Romanian majority population were the same or different compared to the diet diversity differences estimated with respect to other non-Roma minorities. If the estimated differences in diet diversity were the same considering each reference group (Romanians and non-Roma minorities), this would suggest that the variation in the diet is independent
Table 1 Labels and definitions of variables

\begin{tabular}{|c|c|}
\hline Variable & Definition \\
\hline $\mathrm{CM}$ & Number of food items consumed per month \\
\hline SI & Simpson index of diversity \\
\hline EI & Entropy index of diversity \\
\hline income & Total household monthly income (Leu) \\
\hline $\begin{array}{l}\text { share_} \\
\quad \text { allowances }\end{array}$ & Share of allowances in total household monthly income \\
\hline share_salaries & Share of salaries in total household monthly income \\
\hline w_food & Ratio of food expenditure to total household income \\
\hline food_price & Imputed amount paid per kilogram of food (Leu) \\
\hline hh_size & Household size \\
\hline d_children & Dummy variable: 1 if household has at least one dependent child \\
\hline d_working & $\begin{array}{l}\text { Dummy variable: } 1 \text { if household head was working during the reference month (i.e., } \\
\text { employee, employer, self-employed, non-agricultural cooperative member, or member of } \\
\text { agricultural association) }\end{array}$ \\
\hline edu_primary & Dummy variable: 1 if household head has no or primary education \\
\hline edu_secondary & Dummy variable: 1 if household head has lower or upper secondary education \\
\hline edu_tertiary & Dummy variable: 1 if household head has university degree \\
\hline d_male & Dummy variable: 1 if household head is male \\
\hline age & Age of household head \\
\hline d_romanian & Dummy variable: 1 if household head declares Romanian nationality \\
\hline d_hungarian & Dummy variable: 1 if household head declares Hungarian nationality \\
\hline d_gypsy & Dummy variable: 1 if household head declares Gypsy (Roma) nationality \\
\hline d_other & Dummy variable: 1 if household head declares other nationality \\
\hline q1 & Dummy variable: 1 if 1 st quarter of the season \\
\hline q3 & Dummy variable: 1 if 3 rd quarter of the season \\
\hline trend & Trend variable (from 2004 to 2011 ) \\
\hline urban & Dummy variable: 1 if household resides in urban area \\
\hline d_bucharest & Dummy variable: 1 if household resides in area of the Bucharest-Ilfov development region \\
\hline
\end{tabular}

Source: Household Budget Survey of Romania; own processing 
Table 2 Distribution of ethnic groups in the Romanian HBS data

\begin{tabular}{llll}
\hline Group & Frequency & Percent & Cumulative \\
\hline Romanian & 115,978 & 90.68 & 90.68 \\
Hungarian & 8126 & 6.35 & 97.04 \\
Roma & 2654 & 2.07 & 99.11 \\
Other minorities & 1137 & 0.89 & 100.00 \\
Total & 127,894 & 100.00 & \\
\hline
\end{tabular}

Source: Household Budget Survey of Romania; authors' calculations

from the choice of reference group. In this case we could conclude that indeed the Roma population is unique not only with respect to the majority Romanian population but also compared to other distinct minority groups. In other words, this would suggest that Roma attain different diet diversity with respect to the majority Romanian population and other non-Roma minorities as well as that the causes explaining them are Roma specific. That is, this would be an indirect confirmation of Hypotheses 1 and 2.

\section{Empirical results}

\subsection{Descriptive statistics}

Descriptive statistics of the HBS survey show a systematic difference in food consumption patterns between Roma, on the one hand, and the majority Romanian population and nonRoma minorities, on the other hand. Figure 1 (Panel a) depicts the development of the share of food expenditure in the total income by ethnic group in Romania. The share for Roma is significantly higher (by more than 15\%) than for other ethnic groups. For all ethnic groups the ratio declined over time but the difference between Roma and non-Roma was largely maintained. Note that the share of food expenditures of Hungarian and other non-Roma minorities show similar patterns with the majority Romanian population in terms of magnitude and trend over time.

Roma's diet diversity as measured by the number of food items consumed, and Simpson and Entropy indices, is lower by between 15 and $18 \%$ than the diet diversity of Romanians or Hungarians (Fig. 1, Panels b, c, d). These results indicate a significant gap in diet diversity between Roma and non-Roma ethnic groups. However, some of these differences could be caused by different socio-economic characteristics of households.

There are also important differences in the diet composition between Roma and other ethnic groups. Roma's diet has on average a higher proportion of cereals and a lower proportion of dairy products and fruits and vegetables relative to other ethnic groups, while differences in diet composition between non-Roma minorities and Romanians seem to be insignificant (Fig. 2). These results suggest that Roma households obtain macronutrients and calories from cheaper food sources such as cereals and low quality condiments than Romanians or nonRoma minorities living in Romania.

Table 3 reports descriptive statistics of households from which it follows that the Roma ethnic group has lower levels of education, larger household size, and more children per household than other ethnic groups in Romania. Roma purchase cheaper food and have lower incomes than Romanians or non-Roma minorities. These differences between Roma and non-Roma indicate that household characteristics may also explain a part of the observed differences in the diet quality between the ethnic groups.

\subsection{Decomposition results}

The estimates from the Blinder-Oaxaca decomposition analysis are reported in Tables 4, 5 and 6 . We present results of the decomposition separately for the Roma minority group relative to each of the three reference (control) groups. Table 4 presents results for Roma compared to the Romanian majority. Table 5 shows the results for Roma versus the Hungarian minority, while Table 6 reports the differential decomposition for Roma compared to other minorities. In all three tables first, we report the mean predictions of diet diversity for the three diversity indicators and their differences between groups. ${ }^{9}$ Next, the diet differentials are decomposed into two main parts: the explained (endowment) effect, reflecting differences in the observed factors with the associated estimated coefficients, and the unexplained effect, of unobserved factors. The unexplained part is further divided into two subcomponents measuring factors in favour of group $A$ 's diet diversity, $U_{A}$, and factors against group $B$ 's diet diversity, $U_{B}$. A positive value of $U_{A}$ implies that unobserved factors have positive effects on group $A$ 's (the reference group) diet diversity, while a positive value of $U_{B}$ indicates unobserved factors having negative impact on the diet diversity of group $B$ (Roma).

Overall, the results from the Blinder-Oaxaca decomposition show that the Roma's diet is quite different from the majority Romanian population diet and even more so when compared to non-Roma minorities (Hungarians and other minorities). First, there are statistically significant differences between Roma's diet and the diet of non-Roma groups (Romanians, Hungarians and other minorities) for all three diversity indicators. Second, the differences in diet diversity are due not only to differences in explanatory variables such as income, prices, and household characteristics but there is also a substantial unexplained component which significantly exceeds in magnitude the explained component. All the explained and unexplained differentials are statistically significant at the $1 \%$ level.

\footnotetext{
${ }^{9}$ Note that means of the diet diversity scores predicted from the BlinderOaxaca analysis slightly differ from unconditional means presented in Table 3 . This is due to the missing values in some of the explanatory variables used in the decomposition analysis.
} 

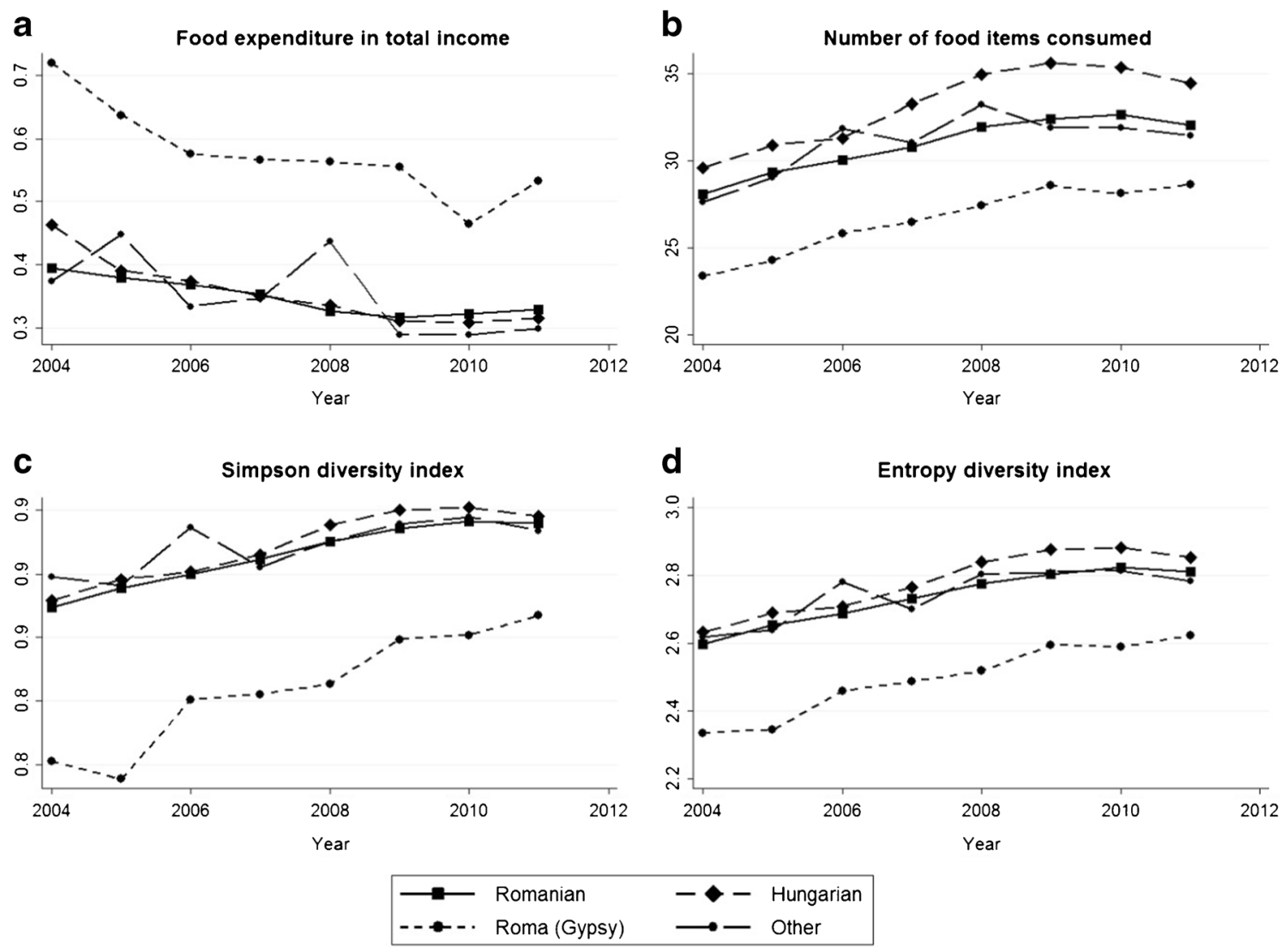

Fig. 1 Evolution of food consumption and diet quality measures across ethnic groups over time. Source: Household Budget Survey of Romania; own processing

As reported in Table 4, the mean of the diet diversity measured by the count of food items consumed (CM) is 30.64 for the reference Romanian group and 25.80 for Roma, yielding a diet diversity gap of 4.837 between the two ethnic groups. The Blinder-Oaxaca technique splits the diet diversity gap into a part that is explained by differences in observed variables and a part that is caused by unobserved factors. The explained

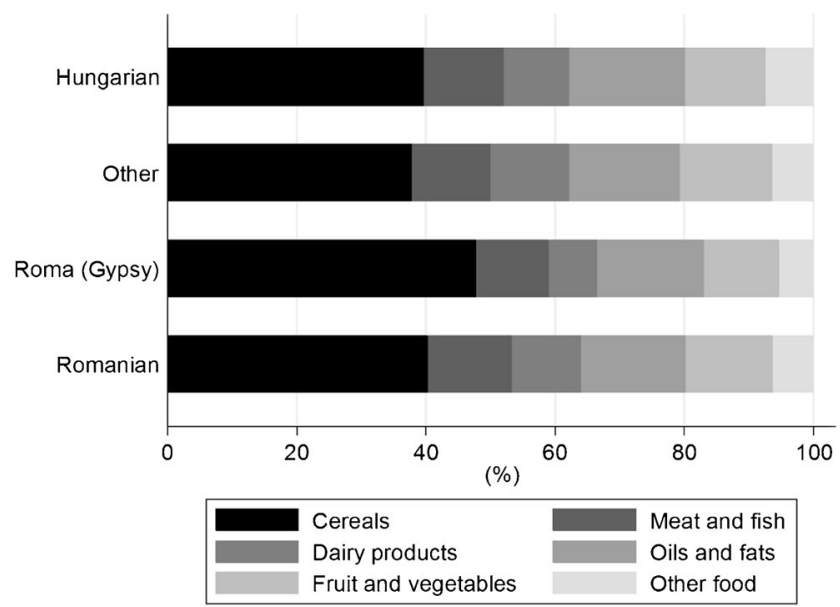

Fig. 2 Composition of diet across ethnic groups. Source: Household Budget Survey of Romania; own processing differential of 1.808 indicates that differences in explanatory variables account for around $37 \%$ of the diet diversity gap, measured by CM, between Roma and the majority Romanian households. The remaining 3.029 indicates that the unexplained component constitutes as much as $63 \%$ of the diet diversity gap of Roma relative to the reference Romanian group. Similar statistically significant results were obtained for the other two indicators of diet quality. The unexplained component accounts for 58\% for the Simpson index and 52\% for the Entropy index of the total gap observed between Roma and Romanians. The remaining share of the Simpson and the Entropy indexes $-42 \%$ and $48 \%$, respectively - is explained by the differences in explanatory variables such as income, prices, and household characteristics.

The decomposition estimates obtained with respect to the control non-Roma minorities are also statistically significant (Table 5, Table 6). First, Roma performed strictly worse than the reference non-Roma minorities. That is, the estimated gaps of the mean values of all three diet quality indicators are positive, implying that non-Roma minorities attain a better quality diet compared to Roma. Second, the estimated diet quality gap of Roma with respect to non-Roma minorities is greater by between 8 and 50\% compared to the gap estimated with respect to Romanians in Table 4. These results imply that Roma 
Table 3 Summary statistics by ethnic groups, 2004-2011

\begin{tabular}{|c|c|c|c|c|c|}
\hline \multirow[b]{2}{*}{ Variable } & \multicolumn{5}{|c|}{ Ethnic group } \\
\hline & Romanian & Hungarian & Roma & Other minorities & Total \\
\hline \multirow[t]{2}{*}{$\mathrm{CM}$} & 32.10 & 34.25 & 27.97 & 32.24 & 32.15 \\
\hline & $(8.360)$ & (8.134) & $(7.829)$ & $(8.254)$ & $(8.373)$ \\
\hline \multirow[t]{2}{*}{ SI } & 0.885 & 0.887 & 0.843 & 0.886 & 0.884 \\
\hline & $(0.0491)$ & $(0.0433)$ & $(0.0715)$ & $(0.0532)$ & $(0.0497)$ \\
\hline \multirow[t]{2}{*}{ EI } & 2.747 & 2.782 & 2.511 & 2.748 & 2.744 \\
\hline & $(0.317)$ & $(0.296)$ & $(0.362)$ & $(0.323)$ & $(0.319)$ \\
\hline \multirow[t]{2}{*}{ income } & 1446.1 & 1304.8 & 839.2 & 1335.6 & 1423.3 \\
\hline & (1118.3) & $(969.5)$ & $(690.0)$ & (1055.8) & (1105.3) \\
\hline \multirow[t]{2}{*}{ share_allowances } & 0.260 & 0.265 & 0.376 & 0.272 & 0.263 \\
\hline & $(0.351)$ & $(0.357)$ & $(0.359)$ & $(0.370)$ & $(0.352)$ \\
\hline \multirow[t]{2}{*}{ share_salaries } & 0.405 & 0.399 & 0.162 & 0.312 & 0.399 \\
\hline & $(0.422)$ & $(0.412)$ & $(0.318)$ & $(0.405)$ & $(0.420)$ \\
\hline \multirow[t]{2}{*}{ w_food } & 0.328 & 0.336 & 0.534 & 0.328 & 0.333 \\
\hline & $(0.214)$ & $(0.195)$ & $(0.257)$ & $(0.186)$ & $(0.215)$ \\
\hline \multirow[t]{2}{*}{ food_price } & 6.385 & 6.445 & 5.678 & 6.473 & 6.375 \\
\hline & $(1.790)$ & (1.686) & $(1.495)$ & $(1.781)$ & $(1.781)$ \\
\hline \multirow[t]{2}{*}{ hh_size } & 2.893 & 2.826 & 4.321 & 2.811 & 2.918 \\
\hline & (1.486) & $(1.372)$ & $(2.192)$ & (1.628) & $(1.512)$ \\
\hline \multirow[t]{2}{*}{ d_children } & 0.317 & 0.305 & 0.630 & 0.275 & 0.322 \\
\hline & $(0.465)$ & $(0.460)$ & $(0.483)$ & $(0.447)$ & $(0.467)$ \\
\hline \multirow[t]{2}{*}{ d_working } & 0.587 & 0.513 & 0.627 & 0.508 & 0.583 \\
\hline & $(0.492)$ & $(0.500)$ & $(0.484)$ & $(0.500)$ & $(0.493)$ \\
\hline \multirow[t]{2}{*}{ edu_primary } & 0.159 & 0.114 & 0.534 & 0.183 & 0.164 \\
\hline & $(0.365)$ & $(0.317)$ & $(0.499)$ & $(0.387)$ & $(0.370)$ \\
\hline \multirow[t]{2}{*}{ edu_secondary } & 0.739 & 0.827 & 0.463 & 0.715 & 0.739 \\
\hline & $(0.439)$ & $(0.378)$ & $(0.499)$ & $(0.452)$ & $(0.439)$ \\
\hline \multirow[t]{2}{*}{ edu_tertiary } & 0.103 & 0.0591 & 0.00276 & 0.103 & 0.0977 \\
\hline & $(0.303)$ & $(0.236)$ & $(0.0525)$ & $(0.304)$ & $(0.297)$ \\
\hline \multirow[t]{2}{*}{ d_male } & 0.745 & 0.730 & 0.792 & 0.719 & 0.745 \\
\hline & $(0.436)$ & $(0.444)$ & $(0.406)$ & $(0.450)$ & $(0.436)$ \\
\hline \multirow[t]{2}{*}{ age } & 54.10 & 54.65 & 45.60 & 56.86 & 53.98 \\
\hline & (16.06) & $(16.02)$ & (14.27) & (16.16) & (16.07) \\
\hline \multirow[t]{2}{*}{ q1 } & 0.499 & 0.492 & 0.487 & 0.508 & 0.498 \\
\hline & $(0.500)$ & $(0.500)$ & $(0.500)$ & $(0.500)$ & $(0.500)$ \\
\hline \multirow[t]{2}{*}{ q3 } & 0.501 & 0.508 & 0.513 & 0.492 & 0.502 \\
\hline & $(0.500)$ & $(0.500)$ & $(0.500)$ & $(0.500)$ & $(0.500)$ \\
\hline \multirow[t]{2}{*}{ trend } & 2007.5 & 2007.5 & 2007.8 & 2007.6 & 2007.5 \\
\hline & $(2.278)$ & $(2.290)$ & $(2.279)$ & (2.293) & $(2.279)$ \\
\hline \multirow[t]{2}{*}{ d_urban } & 0.570 & 0.515 & 0.462 & 0.502 & 0.563 \\
\hline & $(0.495)$ & $(0.500)$ & $(0.499)$ & $(0.500)$ & $(0.496)$ \\
\hline \multirow[t]{2}{*}{ d_bucharest } & 0.115 & 0.00162 & 0.0863 & 0.0524 & 0.107 \\
\hline & $(0.319)$ & $(0.0403)$ & $(0.281)$ & $(0.223)$ & $(0.309)$ \\
\hline $\mathrm{N}$ & 110,557 & 9160 & 2146 & 1158 & 123,021 \\
\hline
\end{tabular}

Note: Standard deviations in parentheses

Source: Household Budget Survey of Romania; authors' calculations 
Table 4 Results of the BlinderOaxaca decomposition analysis: Roma minority compared to Romanian group

\begin{tabular}{|c|c|c|c|}
\hline & \multicolumn{3}{|l|}{ Dependent variable } \\
\hline & Number of food items & Simpson index & Entropy index \\
\hline \multicolumn{4}{|l|}{ I. Differential } \\
\hline \multirow[t]{2}{*}{ Prediction (Romanian) } & $30.64^{* * * *}$ & $0.883^{* * *}$ & $2.718^{* * *}$ \\
\hline & $(0.027)$ & $(0.000)$ & $(0.001)$ \\
\hline \multirow[t]{2}{*}{ Prediction (Roma) } & $25.80^{* * * *}$ & $0.837^{* * * *}$ & $2.450^{* * * *}$ \\
\hline & $(0.309)$ & $(0.002)$ & $(0.011)$ \\
\hline \multirow[t]{2}{*}{ Difference } & $4.837^{* * *}$ & $0.0461^{* * * *}$ & $0.269^{* * *}$ \\
\hline & $(0.311)$ & $(0.002)$ & $(0.011)$ \\
\hline \multicolumn{4}{|l|}{ II. Decomposition } \\
\hline \multirow[t]{2}{*}{ Explained (Total) } & $1.808^{* * *}$ & $0.0192^{* * *}$ & $0.128^{* * *}$ \\
\hline & $(0.047)$ & $(0.000)$ & $(0.002)$ \\
\hline Explained total ( $\%$ of total difference) & 37.38 & 41.65 & 47.58 \\
\hline \multirow[t]{2}{*}{ income } & $3.857^{* * * *}$ & $0.00865^{* * * *}$ & $0.0954^{* * * *}$ \\
\hline & $(0.058)$ & $(0.000)$ & $(0.002)$ \\
\hline \multirow[t]{2}{*}{ income_2 } & $-1.644^{* * * *}$ & $-0.00377^{* * *}$ & $-0.0418^{* * * *}$ \\
\hline & $(0.033)$ & $(0.000)$ & $(0.001)$ \\
\hline \multirow[t]{2}{*}{ share_allowances } & $0.0212^{* * * *}$ & -0.0000538 & -0.0000345 \\
\hline & $(0.006)$ & $(0.000)$ & $(0.000)$ \\
\hline \multirow[t]{2}{*}{ share_salaries } & $-0.0723^{* * * *}$ & $-0.00165^{* * *}$ & $-0.00664^{* * *}$ \\
\hline & $(0.015)$ & $(0.000)$ & $(0.001)$ \\
\hline \multirow[t]{2}{*}{ w_food } & $-1.084^{* * * *}$ & $-0.00103^{* * *}$ & $-0.0216^{\text {**** }}$ \\
\hline & $(0.049)$ & $(0.000)$ & $(0.001)$ \\
\hline \multirow[t]{2}{*}{ food_price } & $0.619^{* * *}$ & $0.00516^{\text {**** }}$ & $0.0381^{* * * *}$ \\
\hline & $(0.013)$ & $(0.000)$ & $(0.001)$ \\
\hline \multirow[t]{2}{*}{ hh_size } & $-0.350^{* * * *}$ & $0.00903^{* * * *}$ & $0.0378^{* * * *}$ \\
\hline & $(0.029)$ & $(0.000)$ & $(0.001)$ \\
\hline \multirow[t]{2}{*}{ d_children } & $-0.689^{* * *}$ & $-0.00202^{* * *}$ & $-0.0175^{* * *}$ \\
\hline & $(0.020)$ & $(0.000)$ & $(0.001)$ \\
\hline \multirow[t]{2}{*}{ d_working } & $-0.0149^{* * * *}$ & $-0.000251^{* * * *}$ & $-0.00103^{* * * *}$ \\
\hline & $(0.003)$ & $(0.000)$ & $(0.000)$ \\
\hline \multirow[t]{2}{*}{ edu_primary } & $0.255^{* * * *}$ & $0.00180^{* * * *}$ & $0.0132^{* * * *}$ \\
\hline & $(0.014)$ & $(0.000)$ & $(0.001)$ \\
\hline \multirow[t]{2}{*}{ edu_secondary } & $0.136^{* * *}$ & -0.000135 & $0.00175^{* * *}$ \\
\hline & $(0.011)$ & $(0.000)$ & $(0.000)$ \\
\hline \multirow[t]{2}{*}{ edu_tertiary } & $0.0266^{* * * *}$ & $0.0000985^{* *}$ & $0.00123^{* * * *}$ \\
\hline & $(0.006)$ & $(0.000)$ & $(0.000)$ \\
\hline \multirow[t]{2}{*}{ d_male } & $0.0530^{* * * *}$ & $0.000398^{* * * *}$ & $0.00313^{* * *}$ \\
\hline & $(0.003)$ & $(0.000)$ & $(0.000)$ \\
\hline \multirow[t]{2}{*}{ age } & $0.872^{* * * *}$ & $0.00323^{* * * *}$ & $0.0325^{* * * *}$ \\
\hline & $(0.084)$ & $(0.001)$ & $(0.003)$ \\
\hline \multirow[t]{2}{*}{ age_2 } & $-0.407^{* * * *}$ & $-0.00141^{* *}$ & $-0.0169^{* * *}$ \\
\hline & $(0.080)$ & $(0.001)$ & $(0.003)$ \\
\hline \multirow[t]{2}{*}{ trend } & $0.0138^{* * *}$ & $0.0000563^{* * * *}$ & $0.000421^{* * *}$ \\
\hline & $(0.001)$ & $(0.000)$ & $(0.000)$ \\
\hline d_urban & $0.219^{* * * *}$ & $0.00126^{* * * *}$ & $0.00991^{* * * *}$ \\
\hline & $(0.005)$ & $(0.000)$ & $(0.000)$ \\
\hline d_bucharest & $-0.00623^{*}$ & $-0.0000768^{* * *}$ & -0.000165 \\
\hline & $(0.003)$ & $(0.000)$ & $(0.000)$ \\
\hline
\end{tabular}


Table 4 (continued)

\begin{tabular}{llll}
\hline & \multicolumn{2}{l}{ Dependent variable } & \\
\cline { 2 - 4 } & Number of food items & Simpson index & Entropy index \\
\hline Unexplained total & $3.029^{* * * *}$ & $0.0269^{* * *}$ & $0.141^{* * * *}$ \\
Unexplained total (\% of total difference) & $(0.315)$ & $(0.002)$ & $(0.012)$ \\
Unexplained A (Romanian) & 62.62 & 58.35 & 52.42 \\
Unexplained B (Roma) & 0.00502 & 0.0000240 & 0.000249 \\
& $(0.003)$ & $(0.000)$ & $(0.000)$ \\
& $3.024^{* * *}$ & $0.0269^{* * *}$ & $0.141^{* * * *}$ \\
\hline
\end{tabular}

Note: Robust standard errors in parentheses; ${ }^{*} p<0.05,{ }^{* *} p<0.01,{ }^{* * *} p<0.001$. The results for seasonal dummies $(q 1, q 3)$ are not reported in the table but were considered in estimations

Source: Household Budget Survey of Romania; authors' calculations

perform worse relative to non-Roma minorities than they do with respect to the majority Romanians. That is, Roma have lower diet diversity than Romanians and even lower than nonRoma minorities (Table 4, Table 5 and Table 6). Given that the absolute values of the estimated differential in diet diversity of Roma relative to the reference Romanian population (Table 4) are lower than the absolute values of differentials estimated with respect to non-Roma minorities (Table 5 and Table 6), non-Roma minorities tend to attain a better diet quality than the majority Romanian population.

The decomposition results for the explained differentials (gap) show that most explanatory variables causing the explained part of the diet diversity gap are statically significant (Table 4, Table 5 and Table 6). Note that a positive estimated coefficient suggests that its corresponding variable increases the explained diet differentials (i.e., it is associated with a larger explained gap in the diet diversity) of Roma relative to the reference non-Roma households. A negative coefficient suggests an opposite result; it is associated with a smaller explained gap in the diet quality of Roma compared to non-Roma. As expected, the explained part of the diet gap due to lower Roma income (larger income differential) is positive on aggregate. The linear income part (income) increases the gap, whereas the squared term (income_2) decreases the gap suggesting that households with higher income attain better diet diversity as compared to low income households. These results are consistent across all three diversity indicators and reference groups. The employment related explanatory variables accounting for the importance of salary in total income (share_salaries) and labour market participation (d_working) are generally negative and thus reduce the explained part of the diet quality gap between Roma and nonRoma. These results indicate that salaried income and availability of jobs help Roma to improve their diet diversity (or reduce the gap) relative to non-Roma. The importance of allowances in total income (share_allowances) appears to be positive but fewer times statistically significant than the above three income and employment variables across the three diversity indices and reference groups. An exception are the estimates for Roma compared to the Romanian group (Table 4) where the estimated coefficient corresponding to allowances is negative in Simpson and Entropy index specifications. These results provide some evidence that the higher Roma dependency on state allowances reduces their diet diversity differential. Thus, the results corresponding to variables share_salaries, $d$ _working and share allowances provide empirical support for Hypothesis 2.

The impact on explained differentials of food expenditure in total disposable income ( $w$ food) appears to be negative and statistically significant across most diversity indices and reference groups. Considering the fact that the food expenditure share of Roma is larger than the share of non-Roma, reducing the gap in food expenditure shares would lead to increase in the diet diversity gap. In contrast, the impact on the explained gap of food prices (food price) is positive and statistically significant across all three diversity indices and reference groups. Higher food price differentials increase the diet gap between Roma and the reference non-Roma households (Table 4, Table 5 and Table 6). These results suggest that Roma are more susceptible to food price fluctuations compared to non Roma. Similar evidence was found in the literature which shows that higher prices have a particular impact on poor and vulnerable populations (e.g., Meerman and Aphane 2012; Green et al. 2013).

Household characteristics have a mixed impact on the explained part of diet diversity. The dummy accounting for the presence of children in the household (d_children) is negative, the dummies accounting for household male head (d_male) and primary education (edu_primary) are generally positive, while other household characteristics ( $h h_{-}$size, edu_secondary, edu_tertiary, age, age_2) have mixed effects across diversity indices and reference groups (Table 4, Table 5 and Table 6). Overall, it appears that higher education is associated with widening the diet diversity gap. This is an important finding suggesting that Roma are less affected by education which generally has a positive effect on diet diversity choices. The 
Table 5 Results of the BlinderOaxaca decomposition analysis: Roma minority compared to Hungarian group

\begin{tabular}{|c|c|c|c|}
\hline & \multicolumn{3}{|l|}{ Dependent variable } \\
\hline & Number of food items & Simpson index & Entropy index \\
\hline \multicolumn{4}{|l|}{ I. Differential } \\
\hline \multirow[t]{2}{*}{ Prediction (Hungarian) } & $32.96^{* * * *}$ & $0.887^{* * *}$ & $2.766^{* * *}$ \\
\hline & $(0.100)$ & $(0.001)$ & $(0.004)$ \\
\hline \multirow[t]{2}{*}{ Prediction (Roma) } & $25.80^{* * * *}$ & $0.837^{* * * *}$ & $2.450^{* * * *}$ \\
\hline & $(0.309)$ & $(0.002)$ & $(0.011)$ \\
\hline \multirow[t]{2}{*}{ Difference } & $7.164^{* * * *}$ & $0.0496^{* * * *}$ & $0.316^{* * * * *}$ \\
\hline & $(0.325)$ & $(0.002)$ & $(0.012)$ \\
\hline \multicolumn{4}{|l|}{ II. Decomposition } \\
\hline \multirow[t]{2}{*}{ Explained (Total) } & $1.656^{* * *}$ & $0.0174^{* * *}$ & $0.115^{* * *}$ \\
\hline & $(0.140)$ & $(0.001)$ & $(0.006)$ \\
\hline Explained total (\% of total difference) & 23.12 & 35.08 & 36.39 \\
\hline \multirow[t]{2}{*}{ income } & $2.965^{* * * *}$ & $0.00696^{* * * *}$ & $0.0759^{* * * *}$ \\
\hline & $(0.142)$ & $(0.001)$ & $(0.005)$ \\
\hline \multirow[t]{2}{*}{ income_2 } & $-1.128^{* * *}$ & $-0.00273^{* * *}$ & $-0.0299^{* * *}$ \\
\hline & $(0.085)$ & $(0.000)$ & $(0.003)$ \\
\hline \multirow[t]{2}{*}{ share_allowances } & $0.0837^{* * * *}$ & 0.000126 & $0.00146^{*}$ \\
\hline & $(0.016)$ & $(0.000)$ & $(0.001)$ \\
\hline \multirow[t]{2}{*}{ share_salaries } & $-0.180^{* * * *}$ & $-0.00224^{* * *}$ & $-0.0128^{\text {**** }}$ \\
\hline & $(0.044)$ & $(0.000)$ & $(0.002)$ \\
\hline \multirow[t]{2}{*}{ w_food } & $-0.657^{* * * *}$ & -0.000389 & $-0.0134^{* * *}$ \\
\hline & $(0.073)$ & $(0.001)$ & $(0.003)$ \\
\hline \multirow[t]{2}{*}{ food_price } & $0.804^{* * *}$ & $0.00473^{\text {**** }}$ & $0.0380^{* * * *}$ \\
\hline & $(0.048)$ & $(0.000)$ & $(0.002)$ \\
\hline \multirow[t]{2}{*}{ hh_size } & $-0.542^{* * * *}$ & $0.00862^{* * * *}$ & $0.0334^{\text {**** }}$ \\
\hline & $(0.089)$ & $(0.001)$ & $(0.004)$ \\
\hline \multirow[t]{2}{*}{ d_children } & $-0.710^{* * * *}$ & $-0.00111^{*}$ & $-0.0122^{* * * *}$ \\
\hline & $(0.066)$ & $(0.000)$ & $(0.003)$ \\
\hline \multirow[t]{2}{*}{ d_working } & $-0.0981^{* * *}$ & $-0.000933^{* * *}$ & $-0.00617^{* * *}$ \\
\hline & $(0.024)$ & $(0.000)$ & $(0.001)$ \\
\hline \multirow[t]{2}{*}{ edu_primary } & $0.275^{* * * *}$ & $0.00209^{* * * *}$ & $0.0158^{* * * *}$ \\
\hline & $(0.055)$ & $(0.000)$ & $(0.002)$ \\
\hline \multirow[t]{2}{*}{ edu_secondary } & $0.165^{* * *}$ & $-0.000723^{*}$ & -0.00236 \\
\hline & $(0.050)$ & $(0.000)$ & $(0.002)$ \\
\hline \multirow[t]{2}{*}{ edu_tertiary } & -0.00710 & -0.00000965 & -0.0000753 \\
\hline & $(0.014)$ & $(0.000)$ & $(0.001)$ \\
\hline \multirow[t]{2}{*}{ d_male } & $0.0612^{* * * *}$ & $0.000538^{* * *}$ & $0.00414^{* * *}$ \\
\hline & $(0.013)$ & $(0.000)$ & $(0.001)$ \\
\hline \multirow[t]{2}{*}{ age } & 0.0280 & 0.0000423 & 0.00111 \\
\hline & $(0.289)$ & $(0.002)$ & $(0.012)$ \\
\hline \multirow[t]{2}{*}{ age_2 } & 0.424 & 0.00127 & 0.0124 \\
\hline & $(0.273)$ & $(0.002)$ & $(0.011)$ \\
\hline \multirow[t]{2}{*}{ trend } & 0.00223 & $-0.0000388^{*}$ & -0.000154 \\
\hline & $(0.002)$ & $(0.000)$ & $(0.000)$ \\
\hline d_urban & $0.0432^{* * * *}$ & $0.000670^{* * * *}$ & $0.00475^{* * * *}$ \\
\hline & $(0.009)$ & $(0.000)$ & $(0.000)$ \\
\hline d_bucharest & $0.127^{* * *}$ & 0.000574 & $0.00512^{* *}$ \\
\hline & $(0.033)$ & $(0.000)$ & $(0.002)$ \\
\hline
\end{tabular}


Table 5 (continued)

\begin{tabular}{llll}
\hline & \multicolumn{2}{l}{ Dependent variable } & \\
\cline { 2 - 4 } & Number of food items & Simpson index & Entropy index \\
\hline Unexplained (Total) & $5.507^{* * * *}$ & $0.0322^{* * * *}$ & $0.201^{* * * *}$ \\
& $(0.357)$ & $(0.003)$ & $(0.014)$ \\
Unexplained total (\% of total difference) & 76.88 & 64.92 & 63.61 \\
Unexplained A (Hungarian) & 0.0336 & 0.000460 & $0.00352^{*}$ \\
Unexplained B (Roma) & $(0.036)$ & $(0.000)$ & $(0.002)$ \\
& $5.474^{* * *}$ & $0.0318^{* * *}$ & $0.198^{* * *}$ \\
\hline
\end{tabular}

Note: Robust standard errors in parentheses; ${ }^{*} p<0.05,{ }^{* *} p<0.01,{ }^{* * *} p<0.001$. The results for seasonal dummies $(q 1, q 3)$ are not reported in the table but were consider in estimations

Source: Household Budget Survey of Romania; authors' calculations

implication is that Roma, even when highly educated are significantly affected by their specific institutional and cultural norms which is a result in support of our Hypothesis 1.

The estimates for the trend variable (trend) suggest that the explained diet gap of Roma increased over time relative to the majority Romanian population (Table 4), whereas it tends to marginally improve relative to other non-Roma minorities (Table 5 and Table 6). The explained differentials due to urban residence ( $d \_$urban $)$are positive and statistically significant at the $1 \%$ level for all three diversity indices and reference groups. Roma residing in urban areas consume a relatively less diverse diet. Roma in rural areas could rely on own supply of food relative to urban households which usually procure food mostly from the market. Alternatively, the urban variable may capture fewer possibilities for employment of Roma which reduces their possibility to earn a higher income, which could sustain a better quality diet (Tables 4, 5 and 6). Interestingly, the impact of the dummy accounting for household residing in the capital region (d_bucharest) on the diet diversity differential is generally negative in the specification with the reference Romanian group (Table 4), while positive in non-Roma minority specifications (Table 5 and Table 6). These estimates suggest that the diet of Roma residing in the capital is relatively more similar to the diet of the Romanian majority, while compared to the non-Roma minorities Roma attain less diverse diet. The results taken together also suggest that the diet quality of non-Roma minorities is better than the diet quality of the Romanian population in Bucharest.

Overall, the estimated statistically significant impact of explanatory variables on the diet diversity gap between Roma and non-Roma is in agreement with the general literature which argues that socio-economic factors affect diet quality of households (e.g., Alaimo et al. 1998; Himmelgreen et al. 2000; Arimond and Ruel 2004; Darmon and Drewnowski 2008; Herzfeld et al. 2014; Codjoe et al. 2016) and more specifically confirms previous findings that lower diet quality of disadvantaged ethnic groups is associated, among other factors, with lower income level, adverse employment opportunities (i.e. lower share of salaried income, lower labour market participation) and lower participation in social assistance programs (e.g., Alaimo et al. 1998; Himmelgreen et al. 2000).

In contrast to the previous findings in the literature, our estimates suggest an important influence of unobserved Roma specific factors in affecting their diet diversity gap with non-Roma. As reported in Tables 4, 5 and 6, the subcomponent, $U_{B}$, of the unexplained part of the diet diversity gap accounts by far for the major share (more than 95\%) of the total unexplained differential and is statistically significant for all three diversity indicators and reference group specifications. These results suggest that unobserved factors lead to lower diet diversity of Roma relative to non-Roma. The subcomponent $U_{A}$ is small and statistically insignificant implying that unobserved factors do not affect non-Roma diet relative to Roma. Similar to the overall gap, the absolute value of the unexplained subcomponent $U_{B}$ for Roma relative to the reference Romanian population is smaller than in the case of nonRoma minorities by between 15 and $80 \%$. These estimates indicate that the unobserved factors impact Roma more than non-Roma minorities in their food diet choices. They suggest that Roma are much more different compared to the nonRoma minorities than they are compared to the majority Romanian population (Tables 4, 5 and 6).

Following these decomposition results, we cannot reject both Hypothesis 1 and Hypothesis 2 that there is a non-trivial incidence of Roma specific factors causing a lower diet diversity compared to other non-Roma ethnic groups, even when controlling for the income level, household characteristics and other structural (observed) characteristics. The unexplained gap estimated with the Blinder-Oaxaca decomposition technique is usually attributed to discrimination in the labour literature (e.g., Drydakis 2012; Croucher et al. 2018). However, a direct association between discrimination and the Roma diet diversity is difficult to identify. Causality could occur through indirect channels. As argued in Hypothesis 2, discrimination affects 
Table 6 Results of the BlinderOaxaca decomposition analysis: Roma minority compared to "Other" minority group

\begin{tabular}{|c|c|c|c|}
\hline & \multicolumn{3}{|l|}{ Dependent variable } \\
\hline & Number of food items & Simpson index & Entropy index \\
\hline \multicolumn{4}{|l|}{ I. Differential } \\
\hline Prediction (other minorities) & $\begin{array}{l}31.03^{* * *} \\
(0.255)\end{array}$ & $\begin{array}{l}0.889^{* * *} \\
(0.002)\end{array}$ & $\begin{array}{l}2.742^{* * * *} \\
(0.011)\end{array}$ \\
\hline Prediction (Roma) & $\begin{array}{l}25.80^{* * * *} \\
(0.309)\end{array}$ & $\begin{array}{l}0.837^{* * * *} \\
(0.002)\end{array}$ & $\begin{array}{l}2.450^{* * * *} \\
(0.011)\end{array}$ \\
\hline Difference & $\begin{array}{l}5.229^{* * * *} \\
(0.401)\end{array}$ & $\begin{array}{l}0.0515^{* * * *} \\
(0.003)\end{array}$ & $\begin{array}{l}0.293^{* * * *} \\
(0.016)\end{array}$ \\
\hline \multicolumn{4}{|l|}{ II. Decomposition } \\
\hline Explained (Total) & $\begin{array}{l}1.543^{* * *} \\
(0.216)\end{array}$ & $\begin{array}{l}0.0192^{* * * *} \\
(0.002)\end{array}$ & $\begin{array}{l}0.125^{* * *} \\
(0.010)\end{array}$ \\
\hline $\begin{array}{l}\text { Explained total (\% of total difference) } \\
\text { income }\end{array}$ & $\begin{array}{l}29.51 \\
2.726^{* * *} \\
(0.260)\end{array}$ & $\begin{array}{l}37.28 \\
0.00594^{* *} \\
(0.002)\end{array}$ & $\begin{array}{l}42.66 \\
0.0726^{* * *} \\
(0.010)\end{array}$ \\
\hline income_2 & $\begin{array}{l}-1.388^{* * * *} \\
(0.181)\end{array}$ & $\begin{array}{l}-0.00297^{* * *} \\
(0.001)\end{array}$ & $\begin{array}{l}-0.0372^{* * * *} \\
(0.007)\end{array}$ \\
\hline share_allowances & $\begin{array}{l}0.0340 \\
(0.025)\end{array}$ & $\begin{array}{l}0.000382 \\
(0.000)\end{array}$ & $\begin{array}{l}0.00207 \\
(0.001)\end{array}$ \\
\hline share_salaries & $\begin{array}{l}-0.0482 \\
(0.045)\end{array}$ & $\begin{array}{l}-0.00131^{\text {*** }} \\
(0.000)\end{array}$ & $\begin{array}{l}-0.00649^{* * *} \\
(0.002)\end{array}$ \\
\hline w_food & $\begin{array}{l}-0.404^{* * *} \\
(0.119)\end{array}$ & $\begin{array}{l}0.00118 \\
(0.001)\end{array}$ & $\begin{array}{l}-0.00198 \\
(0.006)\end{array}$ \\
\hline food_price & $\begin{array}{l}1.007^{* * * *} \\
(0.093)\end{array}$ & $\begin{array}{l}0.00905^{* * *} \\
(0.001)\end{array}$ & $\begin{array}{l}0.0575^{\text {**** }} \\
(0.004)\end{array}$ \\
\hline hh_size & $\begin{array}{l}-0.291^{*} \\
(0.137)\end{array}$ & $\begin{array}{l}0.00914^{* * *} \\
(0.001)\end{array}$ & $\begin{array}{l}0.0366^{* * * *} \\
(0.006)\end{array}$ \\
\hline d_children & $\begin{array}{l}-1.111^{* * * *} \\
(0.129)\end{array}$ & $\begin{array}{l}-0.00434^{* * *} \\
(0.001)\end{array}$ & $\begin{array}{l}-0.0323^{\text {**** }} \\
(0.006)\end{array}$ \\
\hline d_working & $\begin{array}{l}-0.0403 \\
(0.039)\end{array}$ & $\begin{array}{l}-0.000899^{*} \\
(0.000)\end{array}$ & $\begin{array}{l}-0.00382^{*} \\
(0.002)\end{array}$ \\
\hline edu_primary & $\begin{array}{l}0.376^{\text {**** }} \\
(0.091)\end{array}$ & $\begin{array}{l}0.00138 \\
(0.001)\end{array}$ & $\begin{array}{l}0.0164^{* * *} \\
(0.004)\end{array}$ \\
\hline edu_secondary & $\begin{array}{l}-0.0214 \\
(0.072)\end{array}$ & $\begin{array}{l}0.0000127 \\
(0.001)\end{array}$ & $\begin{array}{l}-0.00206 \\
(0.003)\end{array}$ \\
\hline edu_tertiary & $\begin{array}{l}0.0552 \\
(0.052)\end{array}$ & $\begin{array}{l}-0.000492 \\
(0.001)\end{array}$ & $\begin{array}{l}0.000595 \\
(0.002)\end{array}$ \\
\hline d_male & $\begin{array}{l}0.0486 \\
(0.027)\end{array}$ & $\begin{array}{l}0.000797^{* *} \\
(0.000)\end{array}$ & $\begin{array}{l}0.00458^{* * * *} \\
(0.001)\end{array}$ \\
\hline age & $\begin{array}{l}-0.0473 \\
(0.606)\end{array}$ & $\begin{array}{l}-0.00171 \\
(0.005)\end{array}$ & $\begin{array}{l}-0.00796 \\
(0.028)\end{array}$ \\
\hline age_2 & $\begin{array}{l}0.589 \\
(0.611)\end{array}$ & $\begin{array}{l}0.00270 \\
(0.006)\end{array}$ & $\begin{array}{l}0.0237 \\
(0.029)\end{array}$ \\
\hline trend & $\begin{array}{l}-0.0282^{* *} \\
(0.011)\end{array}$ & $\begin{array}{l}-0.0000651 \\
(0.000)\end{array}$ & $\begin{array}{l}-0.000880 \\
(0.000)\end{array}$ \\
\hline d_urban & $\begin{array}{l}0.0446^{* * *} \\
(0.008)\end{array}$ & $\begin{array}{l}0.000294^{* * * *} \\
(0.000)\end{array}$ & $\begin{array}{l}0.00215^{* * * *} \\
(0.000)\end{array}$ \\
\hline d_bucharest & $\begin{array}{l}0.0488^{* * * *} \\
(0.011)\end{array}$ & $\begin{array}{l}0.000254^{*} \\
(0.000)\end{array}$ & $\begin{array}{l}0.00203^{* * *} \\
(0.001)\end{array}$ \\
\hline
\end{tabular}


Table 6 (continued)

\begin{tabular}{llll}
\hline & \multicolumn{2}{l}{ Dependent variable } & \\
\cline { 2 - 4 } & Number of food items & Simpson index & Entropy index \\
\hline Unexplained (Total) & $3.685^{* * *}$ & $0.0323^{* * *}$ & $0.168^{* * *}$ \\
Unexplained total (\% of total difference) & $(0.466)$ & $(0.003)$ & $(0.019)$ \\
Unexplained A (other minorities) & 0.187 & 62.72 & 57.34 \\
Unexplained B (Roma) & $(0.141)$ & 0.000257 & 0.00448 \\
& $3.498^{* * *}$ & $(0.001)$ & $(0.006)$ \\
& $(0.434)$ & $0.0320^{* * * *}$ & $0.163^{* * *}$ \\
\hline
\end{tabular}

Robust standard errors in parentheses; ${ }^{*} p<0.05,{ }^{* *} p<0.01,{ }^{* * *} p<0.001$. The results for seasonal dummies $(q 1, q 3)$ are not reported in the table but were considered in estimations

Source: Household Budget Survey of Romania; authors' calculations

adversely Roma access to the labour market which reduces their job opportunities, income level and income and job security/stability. We have attempted to control for some of these effects by including among the explanatory variables household monthly income (income), the share of allowances in total household income (share_allowances), the share of salaries in total household income (share_salaries) and a dummy variable capturing if the household head was working during the reference month ( $d$ _working). As the above results show these variables explain a share of the total observed diet gap between Roma and non-Roma. Although, these variables may capture some of the adverse labour market effects caused by discrimination, they may not fully account for the complex nature of Roma's marginalisation associated with income insecurity and casual type of jobs they usually face (Hypothesis 2). As a result, following Dercon (2002), a part of the unexplained component of the diet diversity gap of Roma relative to non-Roma could be caused by the risky income stream which is reflected in their inferior nutritional quality.

The unexplained component could also largely be due to the Roma informal institutions. The specificities of Roma informal institutions are difficult to account for in the estimations as the variables to measure them are not readily available. As explained above, Roma institutions and history may have direct and indirect implications for their food consumption. Food preparation and consumption have to respect certain rules and taboos which may constrain Roma diet choices. Restrictions are related to constrained use of food procured from non-Roma, some foods cannot be consumed or can be consumed only at particular events as well as the current eating habits of Roma could be strongly affected by their nomadic way of life practiced in the past when food storage was costly and own food production was limited, potentially leading to lower diet diversity. All these elements are specific to Roma and are likely the cause of the large unexplained relative differential in the Roma diet estimated in this paper compared to the counterfactual non-Roma groups. Thus, these findings support Hypothesis 1.
Our results also show that unobserved factors affect nonRoma minorities to behave less differently relative to the majority Romanian population in term of their dietary choices than Roma do. Also non-Roma minorities tend to attain better diet quality than the majority Romanian population. This greater diet diversity of non-Roma minorities could be caused by the fact that minorities could combine own food dietary habits (cuisine) with that of majority Romanians and thus obtain a richer and more diverse diet. As our results show, this is not the case for Roma. Hence, the findings provide further indirect support for Hypothesis 1. That is, informal institutions appear to constrain Roma to diversify their food diet through adoption of food consumption patterns from non-Roma. Indeed, the food procured from outside, from non-Roma is perceived as undesirable by the Roma value system as defined by Romaniya. Roma informal rules require isolation of all aspects of food preparation and consumption from nonRoma and our results support this by suggesting that it leads to lower Roma diet diversity.

\section{Conclusions and discussion}

The dietary quality of Roma's food is not well understood and has generally not been sufficiently investigated in the literature. This paper attempts to fill this gap in the literature by analysing how Roma dietary diversity compares with that of non-Roma populations in Romania and by providing possible explanations of Roma food diet choices. The paper applies the Blinder (1973) and Oaxaca (1973) decomposition approach and uses the Household Budget Survey (HBS) data from Romania for the period 2004-2011.

Results suggest that Roma have inferior dietary diversity compared to the rest of the population. Around one-third (varying between 23 and 47\%) of the diet gap is explained by the differences in the observed socio-economic factors. The remaining part of around two-thirds (varying between 
57 and $77 \%$ ) of the gap is attributed to discrimination in the labour market (Hypothesis 2) and in particular to their specific informal institutions (Hypothesis 1). Further, our estimates suggest that unobserved factors cause Roma to be much more different from the majority Romanian population than the non-Roma minorities. Thus these estimates provide strong confirmation of the role of Roma-specific factors explaining the diet diversity gap of Roma with respect to non-Roma.

This paper presents new approaches to explain the presence of the diet diversity gap between Roma and non-Roma. A large body of literature argues that food diet diversity is usually determined by socio-economic factors such as income, poverty and education. Although the paper does not fully reject this literature, it provides evidence that an important driver of diet diversity between the studied groups is likely to be caused by informal institutions and traditions. It appears that specific informal institutions and traditions guide Roma in their food composition choices but in an adverse way, causing less diversified diets compared to non-Roma groups.

The findings of this paper may provide guidance for policy initiatives aimed at supporting improvement of food security in general and diet diversity in particular among Roma, as they help to better understand the lack of diet diversity of Roma compared with non-Roma and its causes. The estimated results suggest that the observed dietary gap of Roma cannot be explained solely by standard socio-economic determinants but one needs to take into account also how individual choices are impacted by informal institutions and norms, and histories. These results imply that a policy which targets only economic determinants of food choices may not lead to the equalisation of the food diet between Roma and non-Roma.

Future work in this area is needed to better identify informal institutions' effects on diet diversity differentials between Roma and non-Roma. In our analyses we were not able to include variables directly capturing elements of Roma informal institutions as the data are not readily available. Future work should aim to collect household or individual level data on specificities of Roma informal institutions and traditions. Data should capture household or individual Roma's level of perception of the Romaniya belief system. In particular, it would be important to understand the marimé rules governing restrictions relating to the constrained use of food procured from non-Roma and the prohibition of the consumption of certain food items. Other factors to be considered would be the role of the past nomadic way of life on the present food consumption patterns and the extent of the adoption of food consumption habits (cuisine) from non-Roma. Availability of such data would allow more accurate identification of the role informal institutions play in determining the lack of diversity of Roma's diet and its differences from non-Roma diets.

The dietary diversity indicators used in this paper suffer from some limitations that are largely related to data constraints. First, they do not account for the differences in quality of food consumed by households owing to the unavailability of data. The nutrient quality of the same food item may vary significantly among households and consequently may alter the magnitude of differences in diet quality between the studied groups compared to those captured through diversity indicators. Second, we did not analyse the differences in diet diversity between different members of the household (e.g., children, women, men). The literature shows that dietary diversity (or food security in general) may vary strongly between household members and may respond differently to socio-economic developments for certain groups (e.g., children, women) (Kotze 2003; Quisumbing and Smith 2007; Meerman and Aphane 2012). Finally, despite these limitations, the paper brings new empirical insights about the poor dietary diversity aspect of Roma in Romania and reveals its possible determinants. In future research it would be desirable if additional information were incorporated into our decomposition framework in order to provide a more nuanced analysis of Roma diet quality.

Acknowledgments We thank the National Statistical Institute of Romania for granting access to the Household Budget Survey data.

Funding The authors acknowledge the financial support from the European Commission FP7 FOODSECURE Research Project (Grant No. 290693), the Slovak Research and Development Agency (Grant No. APVV-16-0321), and the Czech Science Foundation (GACR) (Grant No. 16-02760S).

\section{Compliance with ethical standards}

Conflict of interest Pavel Ciaian is employed at the Joint Research Centre of the European Commission. Andrej Cupák is employed at the LIS CrossNational Data Center in Luxembourg and the National Bank of Slovakia. The authors are solely responsible for the content of the paper. The views expressed are purely those of the authors and may not in any circumstances be regarded as stating an official position of the European Commission, the LIS Cross-National Data Center or the National Bank of Slovakia.

Open Access This article is distributed under the terms of the Creative Commons Attribution 4.0 International License (http:// creativecommons.org/licenses/by/4.0/), which permits unrestricted use, distribution, and reproduction in any medium, provided you give appropriate credit to the original author(s) and the source, provide a link to the Creative Commons license, and indicate if changes were made.

\section{References}

Achim, V. (2004). The Roma in Romanian History. Budapest: Central European University Press.

Alaimo, A., Briefel, R. R., Frongillo, E. A., \& Olson, C. M. (1998). Food insufficiency exists in the United States: results from the third National Health and Nutrition Examination Survey (NHANES III). American Journal of Public Health, 88, 419-426.

Alderman, H. (1996). Saving and economic shocks in rural Pakistan. Journal of Development Economics, 51, 343-365. 
Arimond, M., \& Ruel, M. T. (2004). Dietary diversity is associated with child nutritional status: evidence from 11 demographic and health surveys. Journal of Nutrition, 134, 2579-2585.

Barany, Z. (2004). Romani marginality and politics. In H. F. Carey (Ed.), Romania since 1989: politics economics and society (pp. 255-274). Lanham: Lexington Books.

Bartoš, V., Bauer, M., Chytilová, J., \& Matějka, F. (2016). Attention Discrimination: Theory and Field Experiments with Monitoring Information Acquisition. American Economic Review, 106(6), $1437-1475$.

Blinder, A. S. (1973). Wage discrimination: Reduced form and structural estimates. Journal of Human Resources, 8(4), 436-455.

Braha, K., Cupák, A., Pokrivčák, J., Qineti, A., \& Rizov, M. (2017). Economic analysis of the link between diet quality and health: Evidence from Kosovo. Economics and Human Biology, 27, 261-274.

Carletto, C., Zezza, A., \& Banerjee, R. (2013). Towards better measurement of household food security: Harmonizing indicators and the role of household surveys. Global Food Security, 2, 30-40.

Champagne, C. M., Casey, P. H., Connell, C. L., Stuff, J. E., Gossett, J. M., Harsha, D. W., McCabe-Sellers, B., Robbins, J. M., Simpson, P. M., \& Weber, J. L. (2007). Poverty and food intake in rural America: Diet quality is lower in food insecure adults in the Mississippi Delta. Journal of the American Dietetic Association, 107, 1886-1894.

Ciaian, P., \& Kancs, D. (2016a). Causes of the social and economic marginalisation: the role of social mobility barriers for Roma. JRC Technical Report No. EUR 27794, Joint Research Centre, European Commission.

Ciaian, P., \& Kancs, D. (2016b). Causes of the social and economic marginalisation: the role of social mobility barriers for Roma. EERI Research Paper Series No 03/2016, Economics and Econometrics Research Institute.

Codjoe, S. N., Okutu, D., \& Abu, M. (2016). Urban Household Characteristics and Dietary Diversity: An Analysis of Food Security in Accra, Ghana. Food and Nutrition Bulletin, 37(2), 202-218.

Coleman-Jensen, A., Gregory, C., \& Singh, A. (2014). Food security in the United States in 2013, statistical supplement. Table S-3. USDA ERS.

Council of Europe. (2012). Estimates on Roma population in European countries. Document prepared by the Support Team of the Special Representative of the Secretary General of the Council of Europe for Roma Issues, http://www.coe.int/en/web/portal/roma.

Crețan, R., \& Turnock, D. (2009). The gypsy minority in Romania: a study in marginality. Romanian Journal of Geography, 53(1), 33-56.

Croucher, R., Ramakrishnan, S., Rizov, M., \& Benzinger, D. (2018). Perceptions of employability among London's low-paid: 'self-determination' or ethnicity? Economic and Industrial Democracy, 31(1), 109-130.

Darmon, N., \& Drewnowski, A. (2008). Does social class predict diet quality? American Journal of Clinical Nutrition, 87(5), 1107-1117.

Dercon, S. (2002). Income risk, coping strategies and safety nets. World Bank Research Observer, 17(2), 141-166.

Dercon, S., \& Krishnan, P. (2000). Vulnerability, seasonality and poverty in Ethiopia. Journal of Development Studies, 36(6), 25-53.

Drydakis, N. (2012). Roma women in Athenian firms: Do they face wage bias? Ethnic and Racial Studies, 35(12), 2054-2074.

European Commission. (2012). Discrimination in the EU in 2012. Special Eurobarometer 393, 2012, Directorate-General Justice and Directorate-General for Communication, European Commission.

Faber, M., Schwabe, C., \& Drimie, S. (2009). Dietary diversity in relation to other household food security indicators. International Journal of Food Safety, Nutrition and Public Health, 2(1), 1-15.

Fairlie, R. W. (1999). The absence of the African-American owned business: an analysis of the dynamics of self-employment. Journal of Labor Economics, 17(1), 80-108.

FAO. (2015). The State of food insecurity in the world. Rome: Food and Agriculture Organization of the United Nations.
Fernandez, E., D'Avanzo, B., Negri, E., Franceschi, S., \& La Vecchia, C. (1996). Diet diversity and the risk of colorectal cancer in northern Italy. Cancer Epidemiol Biomarkers Prevention, 5(6), 433-436.

FRA. (2012). The situation of Roma in $11 \mathrm{EU}$ member states: survey results at a glance. Results of the UNDP/ World Bank/ European Commission regional Roma 2011 survey. Report prepared by FRA and UNDP, Luxembourg: Publications Office of the European Union.

FRA. (2014a). Roma survey - data in focus; poverty and employment: the situation of Roma in $11 \mathrm{EU}$ member States. European Union Agency for Fundamental Rights and European Commission.

FRA. (2014b). Roma survey - data in focus; discrimination against and living conditions of Roma women in 11 EU Member States. European Union Agency for Fundamental Rights and European Commission.

Fraser, A. (1995). The Gypsies. Offord: Blackwell.

Frenette, M., \& Morissette, R. (2005). Will they ever converge? Earnings of immigrant and Canadian-born workers over the last two decades. International Migration Review, 39(1), 228-258.

Green, R., Cornelsen, L., Dangour, A. D., Turner, R., Shankar, B., Mazzocchi, M., \& Smith, R. D. (2013). The effect of rising food prices on food consumption: systematic review with meta-regression. British Medical Journal, 346, 1-9.

Hatloy, A., Torheim, L. E., \& Oshaug, A. (1998). Food variety - a good indicator of nutritional adequacy of the diet? A case study from an urban area in Mali, West Africa. European Journal of Clinical Nutrition, 52(12), 891-898.

Herzfeld, T., Huffman, S., \& Rizov, M. (2014). The dynamics of food, alcohol and cigarette consumption in Russia during transition. Economics and Human Biology, 13(C), 128-143.

Himmelgreen, D., Pérez-Escamilla, R., Segura-Millán, S., Peng, Y. K., Gonzalez, A., Singer, M., \& Ferris, A. (2000). Food insecurity among low-income Hispanics in Hartford, Connecticut: implications for public health policy. Human Organization, 59(3), 334-342.

Hirvonen, K. (2016). Rural-urban differences in children's dietary diversity in Ethiopia: a poison decomposition analysis. Economics Letters, 147, 12-15.

Hoddinott, J. (1999). Choosing outcome indicators of household food security. Washington D.C: International Food Policy Research Institute.

Hoddinott, J., \& Yohannes, Y. (2002). Dietary diversity as a food security indicator. Food and nutrition technical assistance project, FHI 360, USAID.

Honer, D., \& Hoppie, P. (2004). The enigma of the Gypsy patient. $R N$, 67(8), 33-36.

Jackson, L. (1984). Hierarchic demand and the Engel curve for variety. The Review of Economics and Statistics, 66(1), 8-15.

Jalan, J., \& Ravallion, M. (1999). Are the poor less well insured? Evidence on vulnerability to income risk in rural China. Journal of Development Economics, 58(1), 61-81.

Kant, A. K. (1996). Indexes of overall diet quality: a review. Journal of the American Dietetic Association, 96(8), 785-791.

Kant, A. K. (2004). Dietary patterns and health outcomes. Journal of the American Dietetic Association, 104(4), 615-635.

Kennedy, E. (2004). Dietary diversity, diet quality, and body weight regulation. Nutrition Reviews, 62, S78-S81.

Kotze, D. A. (2003). Role of women in the household economy, food production and food security: Policy guidelines. Outlook on Agriculture, 32, 111-121.

Lee, J. Y., \& Brown, M. G. (1989). Consumer demand for food diversity. Southern Journal of Agricultural Economics, 21, 47-53.

Leeson, P. T. (2013). Gypsy law. Public Choice, 155, 273-292.

Marushiakova, E., \& Popov, V. (2003). Ethnic identities and economic strategies of the gypsies in the countries of the former USSR. In T. Herzog \& W. Holzwarth (Eds.), Nomaden und Sesshafte - Fragen, Methoden, Ergebnisse (pp. 289-310). Halle: Orientwissenschaftliche Zentrum.

Masseria, C., Mladovsky, P., \& Hernndez-Quevedo, C. (2010). The socio-economic determinants of the health status of Roma in 
comparison with non-Roma in Bulgaria, Hungary and Romania. European Journal of Public Health, 20(5), 549-554.

Matz, J. A., Kalkuhl, M., \& Abegaz, G. A. (2015). The short-term impact of price shocks on food security-Evidence from urban and rural Ethiopia. Food Security, 7(3), 657-679.

Meerman, J., \& Aphane, J. (2012). Impact of high food prices on nutrition. Proceedings on "Expert Consultation on Policy Responses to High and Volatile Food Prices", FAO.

Năstasă, L., \& Salat, L. (2003). Relații interetnice în România postcomunistă. Cluj-Napoca: Centrul de Resurse pentru Diversitate Etnoculturală.

Neumark, D. (1988). Employers' discriminatory behavior and the estimation of wage discrimination. Journal of Human Resources, 23(3), 279-295.

O'Higgins, N., \& Ivanov, A. (2006). Education and employment opportunities for the Roma. Comparative Economic Studies, 48, 6-19.

Oaxaca, R. (1973). Male-female wage differentials in urban labor markets. International Economic Review, 14, 693-709.

Oaxaca, R. L., \& Ransom, M. R. (1994). On discrimination and the decomposition of wage differentials. Journal of Econometrics, 61(1), 5-21.

Patrin. (2015). Romani customs and traditions: Roma beliefs, Romaniya. The Patrin Web Journal: Romani Culture and History, http://www. oocities.org/ patrin/beliefs.htm, Downloaded March 2015.

Quisumbing, A. R., \& Smith, L. C. (2007). Intrahousehold allocation, gender relations, and food security in developing Countries. In P. Pinstrup-Andersen \& F. Cheng (Eds.), Food policy for developing countries: The role of government in the global food system. Ithaca: Cornell University.

Ruel, M. T. (2002). Is dietary diversity an indicator of food security or dietary quality? A review of measurement issues and research needs. FCND Discussion Paper No. 140, International Food Policy Research Institute.

Schaafsma, J., \& Sweetman, A. (2001). Immigrant Earnings: age at immigration matters. Canadian Journal of Economics, 34(4), 1066 1099.

Sen, B. (2014). Using the Oaxaca-Blinder decomposition as an empirical tool to analyze racial disparities in obesity. Obesity, 22, 1750-1755.

Theil, H., \& Finke, R. (1983). The consumer's demand for diversity. European Economic Review, 23(3), 395-400. https://doi.org/10. 1016/0014-2921(83)90039-9.

Thiele, S., \& Weiss, C. (2003). Consumer demand for food diversity: evidence for Germany. Food Policy, 28(2), 99-115. https://doi.org/ 10.1016/S0306-9192(02)00068-4

Tomovska, I. (2010). Poverty, discrimination and the Roma: a human security issue. Human Security Perspectives, 7, 63-82.

Troc, G. (2002). A state of despair: Roma (Gypsy) population during transition - Transylvanian case studies. Studia Europaea, 47(1-2), 49-90.

UNDP. (2013). Incomes, expenditures and consumption of households in marginalized Roma settlements. United Nations Development Programme (UNDP), http://www.romadecade.org/cms/upload/file/ 9720_file1_gen_eng_finalweb.pdf.

UNDP. (2014). Faces of poverty, faces of hope. New York: United Nations Development Programme.

Voko, Z., Csepe, P., Nemeth, R., Kosa, K., Kosa, Z., Szeles, G., \& Adany, R. (2009). Does socioeconomic status fully mediate the effect of ethnicity on the health of Roma people in Hungary? Journal of Epidemiology and Community Health, 63, 455-460.

Weyrauch, W. O. (Ed.). (2001). Gypsy law: Romani legal traditions and culture. Berkeley: University of California Press.

World Bank. (2005). Roma social mapping. București: World Bank http:// www.anr.gov.ro/docs/statistici/Roma_Social_Mapping_187.pdf.

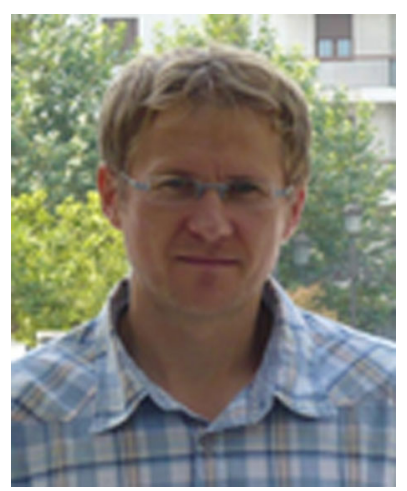

Pavel Ciaian is a senior researcher and team leader of Economic Analyses of Food Supply Chains at the Joint Research Centre of the European Commission. His research interests include agricultural and food policy impact analysis, food security, food chains, institutional economics and agricultural economics.

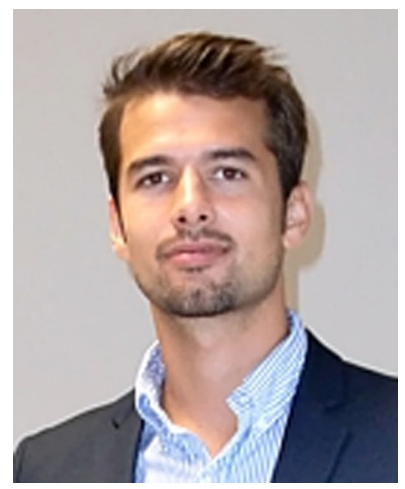

Andrej Cupák is a researcher at the LIS Cross-National Data Center in Luxembourg and the National Bank of Slovakia. His research interests include household financial decision-making, consumer behaviour, survey data, and applied microeconometrics.

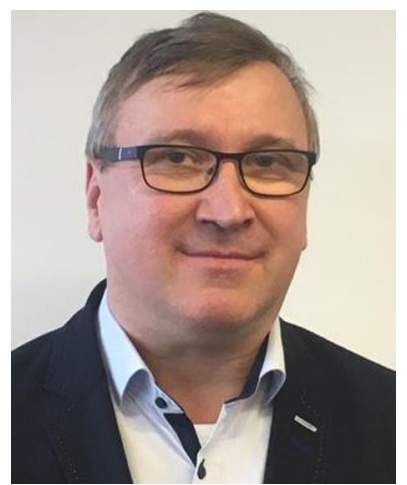

Ján Pokrivčák is Professor of Economics at the Faculty of Economics and Management of the Slovak University of Agriculture in Nitra. His research interests include agricultural policy analysis, food security, political economy and institutional economics.

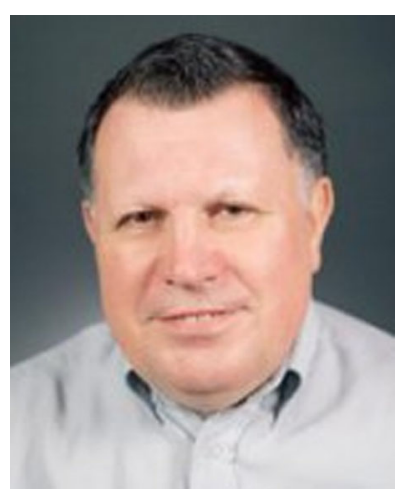

Marian Rizov is Professor of Economics at the Lincoln Business School of the University of Lincoln. His main research interests concern applied microeconomics and finance. Initially, trained as an agricultural economist, he has developed a diverse research portfolio covering economic development and productivity, food economics and agribusiness, labour economics and industrial relations. 